\title{
30. SEDIMENT FACIES AND ENVIRONMENTS OF DEPOSITION ON CRETACEOUS PACIFIC CARBONATE PLATFORMS: AN OVERVIEW OF DREDGED ROCKS FROM WESTERN PACIFIC GUYOTS ${ }^{1}$
}

\author{
Robert J. van Waasbergen ${ }^{2}$
}

\begin{abstract}
Many years of dredging of Cretaceous guyots in the western Pacific Ocean have shown the widespread occurrence of drowned carbonate platforms that were active in the Early to middle Cretaceous. Through petrographic analysis of available dredged limestone samples from these guyots, eight limestone lithofacies are distinguished, of which the first three are found in great abundance or in dredges from more than one guyot. The eight lithofacies are used to form a composite image of the depositional environments on the Cretaceous Pacific carbonate platforms. The most abundant facies (Facies 1) is a coarse bioclastic grainstone found in the forereef environment. Facies 2 comprises mudstone in which small bioclasts are rare to abundant. This facies is typical of the platform-interior ("lagoon") environment. Facies 3 comprises packstones and wackestones of peloids and coated grains, and is attributed to deposition in environments of moderate energy dominated by tidal currents.

A number of lithofacies were recognized in only a few samples, or only in samples from a single guyot, and are therefor termed "minor" faciec. Facies 4 comprises muddy sponge-algal bafflestone deposits probably associated with shallow, platform-interior bioherms. Facies 5 comprises oolite grainstones and is attributed to high-energy platform-margin environments. Facies 6 is a mixed carbonate/siliciclastic deposit and may be associated with an episode of renewed volcanic activity on one of the guyots (Allison) in the Mid-Pacific Mountains. Facies 7 is a mixed shallow-water and pelagic sediment, attributed to deposition in the middle-slope environment, seaward from the coarse forereef sands. Facies 8 comprises muddy sediment with a high species diversity. It is attributed to deposition in a near-marginal open-lagoon environment.

The most striking aspect of the recovered lithofacies is the strong contrast in depositional energy presented by the platformmargin and platform-interior facies. The absence of evidence of reef-framework structures at the platform margins suggests that wave and current energy in the open ocean either was not very great in the Cretaceous Pacific Ocean, or was efficiently damped by lack of depositional relief. Early lithification of platform margin sediment by diagenesis may have helped prevent rapid erosion of the platform margin deposits during the buildup of the platforms.
\end{abstract}

\section{INTRODUCTION}

Western Pacific guyots (flat-topped seamounts) are the sites of numerous carbonate platforms that formed during the middle Cretaceous. Many of these platforms, the summits of which were at sea level roughly during the middle Cretaceous, have been the focus of a number of studies (e.g., Menard, 1964; Winterer and Metzler, 1984; Winterer et al., 1993; van Waasbergen and Winterer, 1993). Most of these studies concentrated on the geophysical aspects of the guyot tops and their relationship to the tectonic and volcanic history of the western Pacific seafloor. The expeditions that gathered the necessary geophysical data in many places also collected rock samples of the platform carbonates. During 1992, several of the Cretaceous carbonate platforms were drilled during Legs 143 and 144 of the Ocean Drilling Program, which provided a great amount of new material from a few platforms.

This study examines the sedimentological aspects of the platforms based on the petrographic analyses of limestone samples that were dredged from many different guyot tops in the western Pacific Ocean. Many of the samples used have not previously been described from a sedimentological perspective. The objectives were to identify the various sedimentary environments that were present on the platforms, to examine the oceanographic conditions in the Cretaceous Pacific Ocean, and to arrive at a composite image of a typical Cretaceous Pacific shallow-marine carbonate platform.

\footnotetext{
'Winterer, E.L., Sager, W.W., Firth, J.V., and Sinton, J.M. (Eds.), 1995. Proc. ODP, Sci. Results, 143; College Station, TX (Ocean Drilling Program).

${ }^{2}$ Department of Geosciences, University of Tulsa, Tulsa, OK 74104, U.S.A.
}

\section{PREVIOUS WORK}

Dredged carbonate samples from the Western Pacific Ocean have been studied and described by Hamilton (1956), Heezen et al. (1973), Ladd et al. (1974), and by Grötsch (1991). The work of Hamilton (1956) was of groundbreaking importance: prior to the discovery of Cretaceous limestones during the Scripps Institution of Oceanography (SIO) Mid-Pacific Expedition of 1950, the guyots were thought to be islands of Precambrian age (Hess, 1946) that had sunk below the sea surface by the weight and water-displacement effects of sediments accumulated on the seafloor over eons. Hamilton (1956) described the recovered shallow-marine carbonates only as "coquina ..., cemented by calcium carbonate," "fragments of . . . reef-coral" (quoted from Hamilton, 1956), and as fragments of individual fossil types (corals, stromatoporoids, gastropods, etc.).

Heezen et al. (1973) described shallow-marine limestones dredged during Leg 5 of the 1971 SIO Aries expedition. Their analyses focused mainly on the phosphatization process, which affected much of the limestones dredged from these guyots, and on the biostratigraphic ages of the recovered microfossils and megafossils. Little distinction among lithofacies types (lumped as "bioclastic calcarenites and rudistid limestones" [Heezen et al., 1973]) was made.

Ladd et al. (1974) described shallow-marine limestone dredged from Darwin Guyot during the 1968 SIO Styx expedition (Leg 7). Their analyses focused on constraining the ages of the fossil material, in particular the tests of planktonic foraminifers found in manganese crusts, which they determined to be Albian to Turonian in age, but "probably Cenomanian" (Ladd et al., 1974). The assemblage of fossil gastropods was determined to belong to an intertidal to near-reef environment, based on comparisons to gastropod forms found on modern carbonate platforms.

Grötsch (1991) presented a somewhat more in-depth analysis of some limestone and phosphorite samples recovered during the SIO 


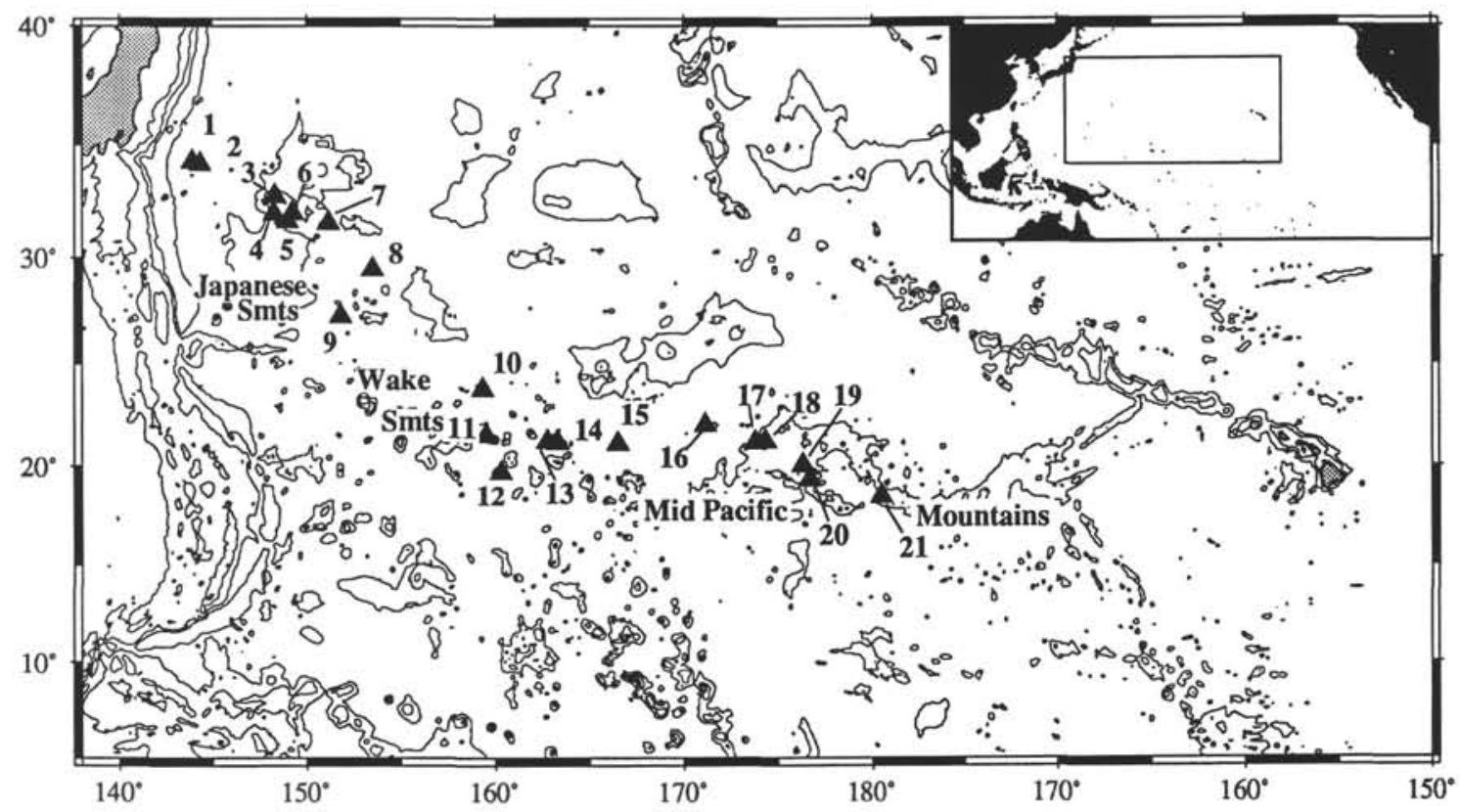

Figure 1. Bathymetry of the western Pacific Ocean, based on DBDB-5 5-min gridded bathymetry. The contour interval is $1000 \mathrm{~m}$. Guyots surveyed during Roundabout Leg 10, are indicated as black triangles. 1: Takuyo-Daini. 2: Takuyo Daisan. 3: "Winterer". 4: "Charlie Johnson". 5: "Stout". 6: “Thomas Washington". 7: Isakov. 8: Makarov. 9: MIT. 10: "Scripps". 11: "Lamont". 12: "Pot". 13: "Vibelius". 14: "Wilde". 15: "Woods Hole". 16: Darwin. 17: "Heezen". 18: Resolution. 19: "Caprina". 20: "Jacqueline". 21: Allison.

Roundabout expedition (Leg 10) and divided the material into "predrowning," "drowning," and "post-drowning" facies. These subdivisions were based largely on the observation of planktonic foraminifers in the shallow-marine rocks, morphologic interpretations of dredge locations, the presence of fossil faunal assemblages associated with deposition in deeper water, or during periods of transgression, and the interpretation of diagenetic features with respect to the history of the movement of the platform summits relative to sea level. Many of the rocks assigned by Grötsch (1991) to a "drowning facies" probably are not. Grötsch (1991) used the lack of meteoric diagenetic features as an argument that the materials had been deposited after the exposure events inferred from morphologic evidence. However, most of the dredged materials came from locations on the outer slopes of the guyot tops, below the level to which the summits had become exposed. Grötsch assumed (based on correlations to events on the Dinaric Platform in Yugoslavia) that the inferred drop in sea level occurred during the late Albian and, therefore, assigned rocks bearing late-Albian-age microfossils to a facies that had been deposited after sea level returned to "normal." I will argue that most, if not all, of the shallow-water facies dredged from the guyot tops were deposited before the events leading to summit exposure took place.

\section{METHODS AND LIMITATIONS}

Limestone rock samples for this study were obtained from the flanks and tops of the guyots by application of the SIO marine rock dredge. The samples were collected during the Styx, Aries, and Roundabout expeditions. Most of the dredges of Aries- 5 and Roundabout-10 (Fig. 1) that recovered shallow-marine limestone were taken upslope on the upper $500 \mathrm{~m}$ of the guyots (Table 1). Some were taken across the flat tops, and a rare few targeted specific bathymetric features (e.g., the top of the outer rim on Resolution Guyot (RNDB10 D65); the insides of karst holes on MIT Guyot, RNDB10 D56).

Much of the material in the dredges consists of slabs of partially to completely phosphatized pelagic and shallow-water limestone, commonly encrusted on both sides with marine manganese-oxyhydroxide deposits up to $25 \mathrm{~cm}$ thick (Ladd et al., 1974). Samples of unphospha- tized limestone were separated for further study from the mass of phosphorite and manganese, along with whole and fragmented megafossils (mostly mollusks), many of which were identified in paleontological studies. Thin sections were prepared of slabbed limestone samples and were studied with a standard petrographic microscope with camera-attachment. Based on observations of grain types, bioclast assemblages, rock-textures, and diagenetic features, three different major and five minor lithologic facies were identified. These are thought to represent different environments of deposition on the Cretaceous platforms. Major facies are those recovered in many dredges, either on multiple guyots or in large amounts in a single dredge. Minor facies are those seen in only a few rock samples from one guyot.

\section{SUMMARY OF CARBONATE LITHOFACIES}

This section briefly introduces the main petrographic aspects of the eight lithofacies. More detailed observations and descriptions of each facies are given in the Appendix. Each facies summary is accompanied by a "cartoon" that shows the typical microscopic features of the sediments. Facies 1, 2, and 3 were dredged from more than one guyot and were generally seen in sufficient abundance in the dredged rocks to be termed "major" facies. Facies 4 through 8 were found on only one guyot and are considered "minor" facies.

\section{Facies 1 (Coarse Bioclastic Grainstone and Packstone)}

This facies consists of abundant skeletal debris of mollusks, with fragments of echinoderms, red- and blue-green algae that form a coarse sandstone to rudstone loosely cemented by fringing, and bladed and syntaxial calcite cement (Fig. 2). The mollusk grains are generally reduced to micrite envelopes, although some can be identified as fragments of caprinid and radiolitid rudists. Algae include solenoporacean and squamaracian (red) algae as well as blue-green Cayeuxia. Echinoderm debris is mostly fragments of cideroid echinoids. Lithoclasts of previously cemented material of similar composition are common. Most of the material has grainstone textures, but some intergranular, pelletal mud occurs, which is in many places phosphatized. 
Table 1. Dredging results from Thomas Washington cruise Roundabout 10, November through December, 1988.

\begin{tabular}{|c|c|c|c|c|c|}
\hline \multirow[b]{2}{*}{ Dredge } & \multicolumn{2}{|c|}{ Location (degrees) } & \multirow{2}{*}{$\begin{array}{c}\text { Depth } \\
\text { range } \\
(\mathrm{m})\end{array}$} & \multirow[b]{2}{*}{ Site } & \multirow[b]{2}{*}{ Contents } \\
\hline & Start & End & & & \\
\hline 49 & $\begin{array}{r}32-49.9 \mathrm{~N} \\
148-24.8 \mathrm{E}\end{array}$ & $\begin{array}{r}32-50.5 \mathrm{~N} \\
148-23.9 \mathrm{E}\end{array}$ & $\begin{array}{l}2344 \\
2996\end{array}$ & "Winterer" Guyot & $5 \mathrm{~kg}$ of altered basalt and volcaniclastic rubble \\
\hline 50 & $\begin{array}{r}31-59.28 \mathrm{~N} \\
148-17.41 \mathrm{E}\end{array}$ & $\begin{array}{r}31-59.6 \mathrm{~N} \\
148-15.6 \mathrm{E}\end{array}$ & $\begin{array}{l}1646 \\
1780\end{array}$ & "Charlie Johnson" Guyot & $1 \mathrm{~kg}$ pumice \\
\hline 51 & $\begin{array}{r}31-58.4 \mathrm{~N} \\
148-19.9 \mathrm{E}\end{array}$ & $\begin{array}{r}31-57.3 \mathrm{~N} \\
148-18.7 \mathrm{E}\end{array}$ & $\begin{array}{l}1700 \\
2087\end{array}$ & "Charlie Johnson" Guyot & $750 \mathrm{~kg}$ phosphorite breccia, coarse bioclastic grainstone, whole rudist shells \\
\hline 52 & $\begin{array}{r}31-53.3 \mathrm{~N} \\
151-12.1 \mathrm{E}\end{array}$ & $\begin{array}{r}31-53.5 \mathrm{~N} \\
148-13.5 \mathrm{E}\end{array}$ & $\begin{array}{l}1750 \\
2375\end{array}$ & "Charlie Johnson" Guyot & $\begin{array}{l}150 \mathrm{~kg} \text { layered phosphorite, bioclastic grainstone and rudstone with mollusk and } \\
\text { echinoid debris }\end{array}$ \\
\hline 53 & $\begin{array}{r}31-30.0 \mathrm{~N} \\
151-12.1 \mathrm{E}\end{array}$ & $\begin{array}{r}31-30.6 \mathrm{~N} \\
151-10.1 \mathrm{E}\end{array}$ & $\begin{array}{l}1655 \\
2375\end{array}$ & Isakov Guyot & $\begin{array}{l}250 \mathrm{~kg} \text { phosphatized pelagic chalk, loose fragments of gastropod and rudist shells, } \\
\text { coarse bioclastic grainstone, one small basalt pebble }\end{array}$ \\
\hline 54 & $\begin{array}{r}31-33.9 \mathrm{~N} \\
151-03.8 \mathrm{E}\end{array}$ & $\begin{array}{r}31-34.1 \mathrm{~N} \\
151-04.7 \mathrm{E}\end{array}$ & $\begin{array}{l}2366 \\
3747\end{array}$ & Isakov Guyot & $30 \mathrm{~kg}$ altered basalt, volcaniclastic debris \\
\hline 55 & $\begin{array}{r}27-25.6 \mathrm{~N} \\
152-02.4 \mathrm{E}\end{array}$ & $\begin{array}{r}27-24.2 \mathrm{~N} \\
152-01.2 \mathrm{E}\end{array}$ & 2537 & MIT Guyot & $25 \mathrm{~kg}$ altered basalt, volcaniclastic debris \\
\hline 56 & $\begin{array}{r}27-13.6 \mathrm{~N} \\
151-44.0 \mathrm{E}\end{array}$ & $\begin{array}{r}27-11.7 \mathrm{~N} \\
151-44.8 \mathrm{E}\end{array}$ & $\begin{array}{l}2537 \\
3200\end{array}$ & MIT Guyot & $35 \mathrm{~kg}$ phosphorite breccia, pelagic chalk, lagoonal mudstone, nerinid gastropod shells. \\
\hline 57 & $\begin{array}{r}23-43.2 \mathrm{~N} \\
159-16.5 \mathrm{E}\end{array}$ & $\begin{array}{r}23-43.5 \mathrm{~N} \\
159-16.5 \mathrm{E}\end{array}$ & $\begin{array}{l}1332 \\
1420\end{array}$ & "Scripps" Guyot & $40 \mathrm{~kg}$ breccia of altered basait in phophatized pelagic matrix \\
\hline 58 & $\begin{array}{r}21-16.2 \mathrm{~N} \\
162-43.6 \mathrm{E}\end{array}$ & $\begin{array}{r}21-17.0 \mathrm{~N} \\
162-43.8 \mathrm{E}\end{array}$ & $\begin{array}{l}1873 \\
1950\end{array}$ & "Vibelius" Guyot & Phosphatized pelagic limestone and manganese oxide \\
\hline 59 & $\begin{array}{r}21-13.4 \mathrm{~N} \\
162-42.6 \mathrm{E}\end{array}$ & $\begin{array}{r}21-14.1 \mathrm{~N} \\
162-43.6 \mathrm{E}\end{array}$ & $\begin{array}{l}1935 \\
2620\end{array}$ & "Vibelius" Guyot & $2.5 \mathrm{~kg}$ phosphorite and manganese, two pieces of silicified oolite \\
\hline 60 & $\begin{array}{r}21-08.6 \mathrm{~N} \\
162-50.3 \mathrm{E}\end{array}$ & $\begin{array}{r}21-10.2 \mathrm{~N} \\
162-50.8 \mathrm{E}\end{array}$ & $\begin{array}{l}2241 \\
3390\end{array}$ & "Wilde" Guyot & Altered basalt and volcaniclastics \\
\hline 61 & $\begin{array}{r}21-06.8 \mathrm{~N} \\
166-27.8 \mathrm{E}\end{array}$ & $\begin{array}{r}21-06.8 \mathrm{~N} \\
166-28.3 \mathrm{E}\end{array}$ & $\begin{array}{l}1840 \\
1310\end{array}$ & "Woods Hole" Guyot & $\begin{array}{l}45 \mathrm{~kg} \text { phosphatized pelagic chalk, rounded basalt pebbles, manganese oxide, fragments } \\
\text { of rudists }\end{array}$ \\
\hline 62 & $\begin{array}{r}21-59.25 \mathrm{~N} \\
171-39.21 \mathrm{E}\end{array}$ & $\begin{array}{r}21-59.4 \mathrm{~N} \\
171-38.5 \mathrm{E}\end{array}$ & $\begin{array}{l}2500 \\
2890\end{array}$ & Darwin Guyot & $5 \mathrm{~kg}$ bioclastic grainstone, packstone and wackestone with abundant coral debris \\
\hline 63 & $\begin{array}{r}21-11.6 \mathrm{~N} \\
173-40.6 \mathrm{E}\end{array}$ & $\begin{array}{r}21-10.4 \mathrm{~N} \\
173-42.3 \mathrm{E}\end{array}$ & $\begin{array}{l}1265 \\
2200\end{array}$ & "Heezen" Guyot & $45 \mathrm{~kg}$ fossiliferous limestone breccia with rudist megafossils, manganese oxide crusts \\
\hline 64 & $\begin{array}{r}21-06.6 \mathrm{~N} \\
173-40.3 \mathrm{E}\end{array}$ & $\begin{array}{r}21-06.8 \mathrm{~N} \\
173-42.3 \mathrm{E}\end{array}$ & $\begin{array}{l}1862 \\
2500\end{array}$ & "Heezen" Guyot & $50 \mathrm{~kg}$ altered basalt and hyaloclastite, and $100 \mathrm{~kg}$ golfball-sized manganese nodules \\
\hline 65 & $\begin{array}{r}21-08.5 \mathrm{~N} \\
174-23.4 \mathrm{E}\end{array}$ & $\begin{array}{r}21-09.1 \mathrm{E} \\
174-24.4 \mathrm{E}\end{array}$ & $\begin{array}{l}1337 \\
1346\end{array}$ & $\begin{array}{l}\text { Resolution Guyot, south margin, } \\
\text { along top of reef-rim }\end{array}$ & $\begin{array}{l}200 \mathrm{~kg} \text { manganese-encrusted rudist pavements, fragments of coralline limestone, } \\
\text { phosphorite }\end{array}$ \\
\hline 66 & $\begin{array}{r}19-11.36 \mathrm{~N} \\
176-41.47 \mathrm{E}\end{array}$ & $\begin{array}{r}19-11.89 \mathrm{~N} \\
176-42.50 \mathrm{E}\end{array}$ & $\begin{array}{l}2681 \\
3100\end{array}$ & "Jacqueline" Guyot & Altered basalt and volcaniclastics, phosphatized pelagic limestone \\
\hline 67 & $\begin{array}{c}18-37.2 \mathrm{~N} \\
179-33.3 \mathrm{~W}\end{array}$ & $\begin{array}{c}18-37.8 \mathrm{~N} \\
179-32.9 \mathrm{~W}\end{array}$ & $\begin{array}{l}1635 \\
1924\end{array}$ & Allison Guyot & Manganese oxide, phosphorite breccia, gastropod packstone \\
\hline 68 & $\begin{array}{r}18-27.3 \mathrm{~N} \\
179-16.6 \mathrm{~W}\end{array}$ & $\begin{array}{c}18-28.6 \mathrm{~N} \\
179-16.4 \mathrm{~W}\end{array}$ & $\begin{array}{l}1435 \\
1773\end{array}$ & Allison Guyot & $350 \mathrm{~kg}$ manganese-encrusted phosphorite breccia, volcaniclastic debris \\
\hline 69 & $\begin{array}{r}18-19.9 \mathrm{~N} \\
179-27.6 \mathrm{~W}\end{array}$ & $\begin{array}{r}18-19.7 \mathrm{~N} \\
179-28.3 \mathrm{~W}\end{array}$ & $\begin{array}{l}2125 \\
2529\end{array}$ & Allison Guyot & $0.2 \mathrm{~kg}$ limestone, sandstone with volcanic and carbonate debris, manganese oxide \\
\hline $\begin{array}{l}70 \\
71\end{array}$ & $\begin{array}{r}18-20.1 \mathrm{~N} \\
179-24.7 \mathrm{~W}\end{array}$ & $\begin{array}{r}18-21.2 \mathrm{~N} \\
179-24.7 \mathrm{~W}\end{array}$ & $\begin{array}{l}2606 \\
2922\end{array}$ & Allison Guyot & $\begin{array}{l}\text { Lost dredge } \\
20 \mathrm{~kg} \text { altered basalt, hyolclastite, phosphorite breccia, coarse bioclastic grainstone }\end{array}$ \\
\hline 72 & $\begin{array}{r}18-40.5 \mathrm{~N} \\
179-43.5 \mathrm{~W}\end{array}$ & $\begin{array}{r}18-40.7 \mathrm{~N} \\
179-41.6 \mathrm{~W}\end{array}$ & $\begin{array}{l}2567 \\
3337\end{array}$ & Allison Guyot & $100 \mathrm{~kg}$ pelagic chalk, manganese-encrusted phosphorite, basalt \\
\hline 73 & $\begin{array}{r}18-22.3 \mathrm{~N} \\
179-27.2 \mathrm{~W}\end{array}$ & $\begin{array}{c}18-21.9 \mathrm{~N} \\
179-26.2 \mathrm{~W}\end{array}$ & $\begin{array}{l}1937 \\
2000\end{array}$ & Allison Guyot & $75 \mathrm{~kg}$ lagoonal bioclastic packstone, pelagic chalk, manganese nodules \\
\hline
\end{tabular}

The mud postdates formation of early fringing spar cement in virtually all samples, but appears to have inhibited the formation of syntaxial cement on echinoid grains. Little to no evidence of compaction is present: even the fragile micrite husks of mollusk shell fragments remain intact.

Coarse bioclastic shell debris was drilled in the interior of Allison and Resolution guyots during Leg 143 (Sites 865 and 866), where they are thought to represent either brief transgressive events over the platform or storm washovers from the rim (Shipboard Scientific Party, 1993a, 1993b). This facies appears to be far more common in dredges from the more northerly Japanese guyots than in dredges from guyots in the Mid-Pacific Mountains (Table 2).

\section{Facies 2 (Mudstone, Fossiliferous Mudstone, and Wackestone)}

Well-lithified lime mud with variable fossil content dominates this facies (Fig. 3), which was found in dredged samples from MIT and Allison guyots (Table 2). The micrite matrix is a mixture of patches of dark, granular mud in a more common tan, finer-grained pelletal mud. Most particles are bioclasts, among which foraminifers are most common. These include benthic agglutinated forms, such as
Cuneolina, textularia, and miliolids. Sand-sized sponge spicules include both massive and hollow forms. Ostracode tests and fragments of green algae are common in samples from Allison Guyot. Mollusk debris consists of very fine, abraded fragments of bivalves and recrystallized fragments of thin-shelled gastropods, but more important are large, often whole, gastropod shells of the type Nerinea.

In most samples, bioclasts of a single type occur in clusters or patches, rather than randomly distributed. This, and the uneven distribution of the different types of matrix, suggests that the sediments were originally deposited in discrete laminae dominated by a single matrixand fossil-type, which became partially mixed by bioturbation. Most smaller bioclasts are dissolved, leaving uncemented molds. The gastropod shells have been replaced with clear, equant, and drusy-mosaic calcite cement, indicating that the mud matrix was recrystallized prior to dissolution of the shells.

\section{Facies 3 (Packstone and Grainstone of Peloids, Ooids, and Coated Grains)}

The most characteristic aspects of this facies are the predominance of coated grains, the variability in abundance and types of bioclasts, and the presence of diagenetically altered rock fragments (Fig. 4). It 

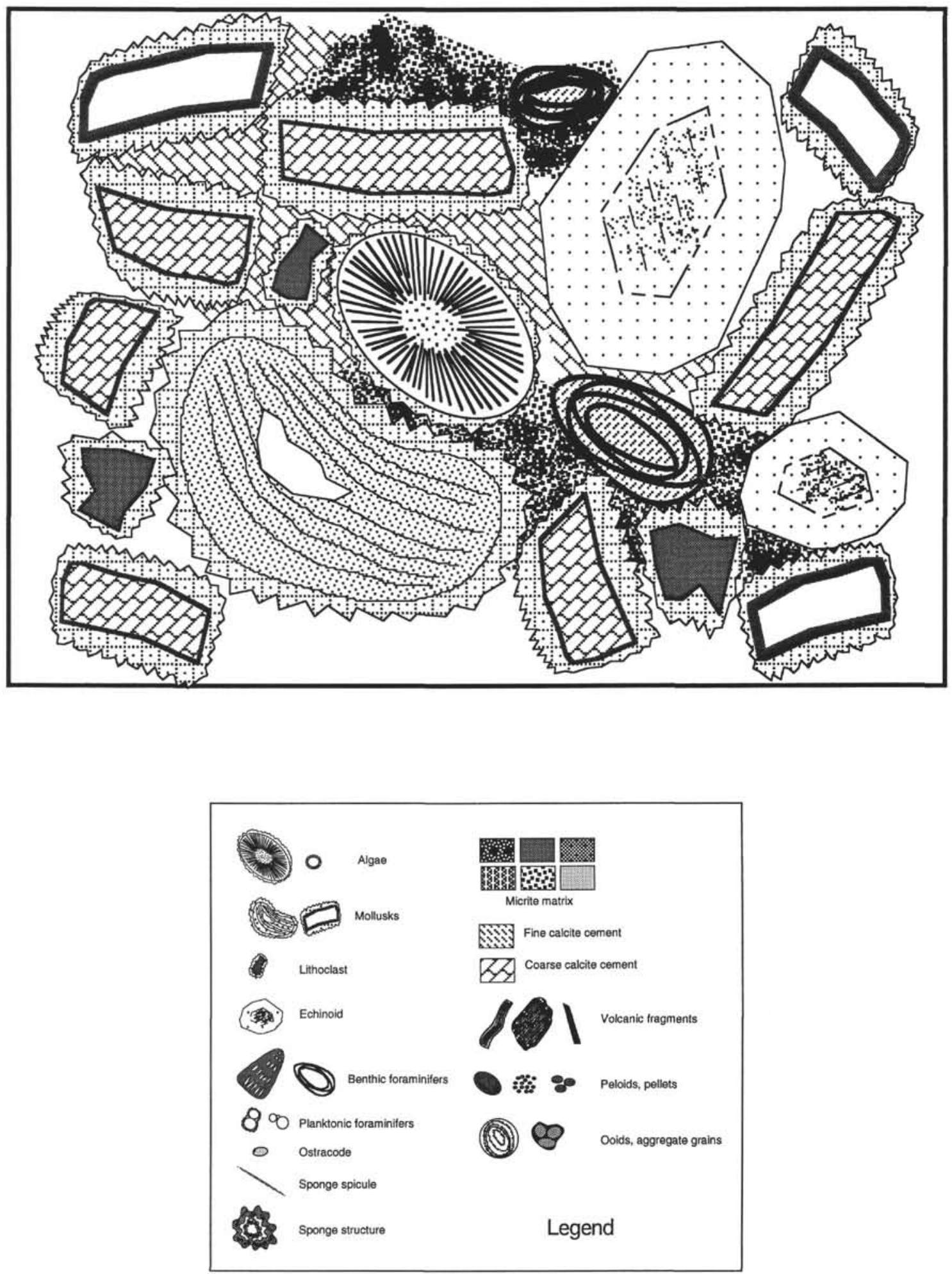

Figure 2. Cartoon representation of Facies 1. Most of the mollusk grains are shown as micrite envelopes or spar-filled molds surrounded with bladed spar cement. The width of the figure represents approximately $4 \mathrm{~mm}$.

was found on platforms in the Japanese and in several of the MidPacific Mountains guyots (Table 2). The matrix consists of fine mud that can be clotted and slightly cemented with microspar, to dense pelletal mud that is somewhat phosphatized in many places. Grains include bioclasts of near-reef (mollusks, red algae, and coral) to platform-interior (foraminifers and green algae) origins. Most abun- dant, however, are a variety of coated grains, including ooids, aggregate grains, and peloids. These suggest thorough reworking, coating, and micritization of sediments was common. Many of the bioclasts are also thickly coated with mud. Rock fragments include abundant mud chips, but also pieces of diagenetically advanced limestone, in which spar-filled veins and stylolites occur. 


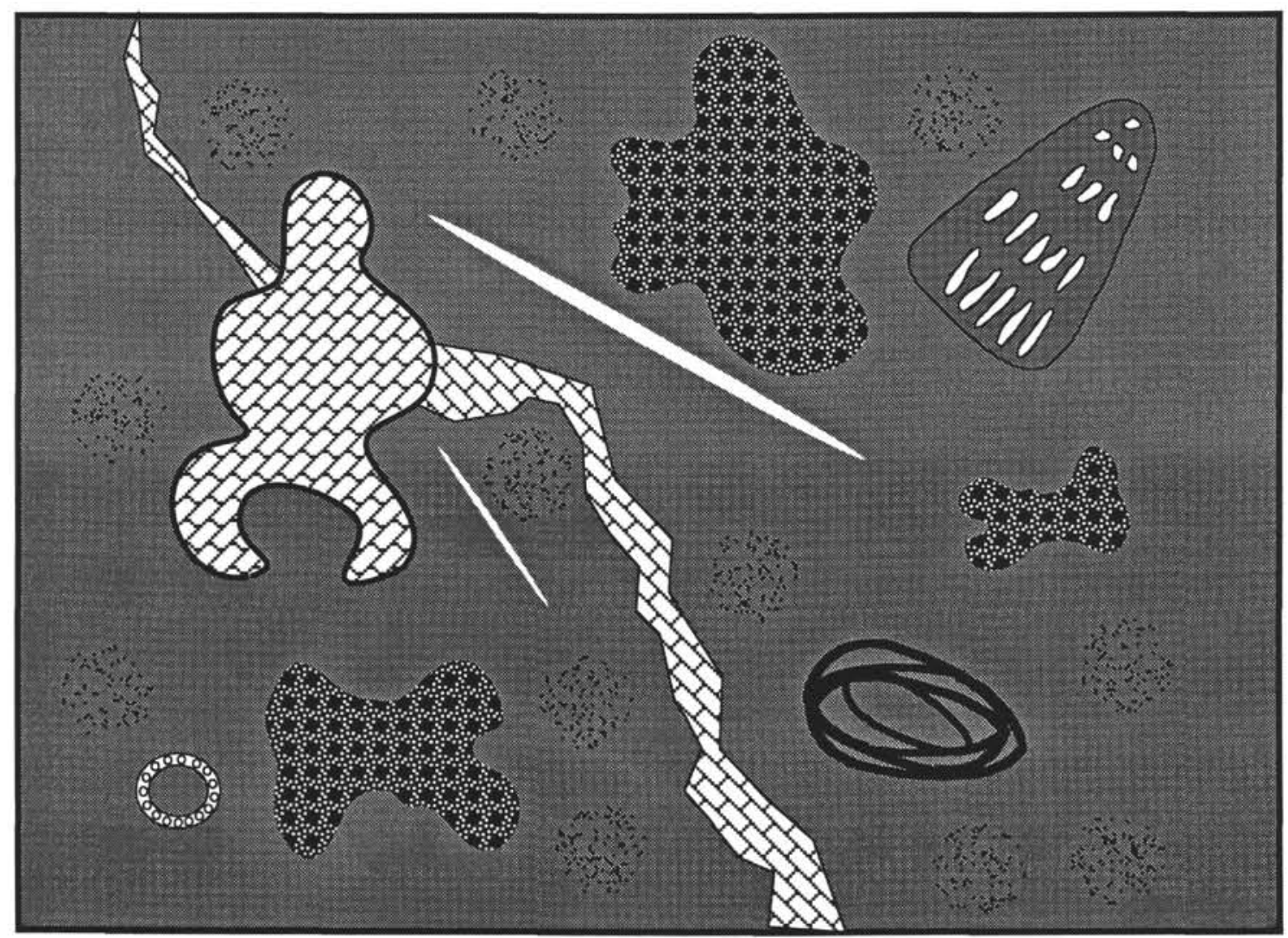

Figure 3. Cartoon representation of Facies 2: Scale and legend as in Figure 2.

Table 2. Facies distribution of dredged limestone samples.

\begin{tabular}{|c|c|c|c|}
\hline Facies & Found on & $\begin{array}{l}\text { Location } \\
\text { (degrees) }\end{array}$ & $\begin{array}{l}\text { Dredge } \\
\text { location }\end{array}$ \\
\hline 1 & $\begin{array}{l}\text { "Charlie Johnson" Guyot } \\
\text { Isakov Guyot } \\
\text { Thomas Washington Guyot } \\
\text { "Winterer" Guyot } \\
\text { Resolution Guyot } \\
\text { "Woods Hole" Guyot } \\
\text { "Jacqueline" Guyot } \\
\text { Takuyo-Daisan Guyot }\end{array}$ & $\begin{array}{l}32.0 \mathrm{~N}, 148.4 \mathrm{E} \\
31.5 \mathrm{~N}, 151.2 \mathrm{E} \\
32.0 \mathrm{~N}, 149.3 \mathrm{E} \\
32.5 \mathrm{~N}, 148.3 \mathrm{E} \\
21.3 \mathrm{~N}, 174.3 \mathrm{E} \\
21.1 \mathrm{~N}, 166.5 \mathrm{E} \\
19.3 \mathrm{~N}, 176.6 \mathrm{E} \\
34.2 \mathrm{~N}, 144.3 \mathrm{E}\end{array}$ & $\begin{array}{l}\text { Upper slope } \\
\text { Upper slope } \\
\text { Upper slope } \\
\text { Upper slope } \\
\text { Marginal rim } \\
\text { Upper slope } \\
\text { Upper slope } \\
\text { Upper slope }\end{array}$ \\
\hline 2 & $\begin{array}{l}\text { MIT Guyot } \\
\text { Allison Guyot }\end{array}$ & $\begin{array}{l}27.3 \mathrm{~N}, 151.8 \mathrm{E} \\
18.5 \mathrm{~N}, 179.5 \mathrm{~W}\end{array}$ & $\begin{array}{l}\text { Center of platform } \\
\text { Slump scar in lagoon sediments }\end{array}$ \\
\hline 3 & $\begin{array}{l}\text { "Charlie Johnson" Guyot } \\
\text { Allison Guyot } \\
\text { "Jacqueline" Guyot } \\
\text { Cape Johnson Guyot }\end{array}$ & $\begin{array}{l}32.0 \mathrm{~N}, 148.4 \mathrm{E} \\
18.5 \mathrm{~N}, 179.5 \mathrm{~W} \\
19.3 \mathrm{~N}, 176.6 \mathrm{E} \\
17.2 \mathrm{~N}, 177.2 \mathrm{~W}\end{array}$ & $\begin{array}{l}\text { Upper slope, platform margin } \\
\text { Slump scar in lagoon sediments } \\
\text { Upper slope } \\
\text { Upper slope }\end{array}$ \\
\hline 4 & Allison Guyot & $18.5 \mathrm{~N}, 179.5 \mathrm{~W}$ & Slump scar in lagoon sediments \\
\hline 5 & "Vibelius" Guyot & $21.2 \mathrm{~N}, 162.8 \mathrm{E}$ & Edge of erosional remnant on summit \\
\hline 6 & Allison Guyot & $18.5 \mathrm{~N}, 179.5 \mathrm{~W}$ & Upper slope, marginal platform \\
\hline 7 & Allison Guyot & $18.5 \mathrm{~N}, 179.5 \mathrm{~W}$ & Slope \\
\hline 8 & Allison Guyot & $18.5 \mathrm{~N}, 179.5 \mathrm{~W}$ & Furrow in summit platform \\
\hline
\end{tabular}

All the samples have packstone textures with little evidence of sorting. Only one sample from Allison Guyot contains fining-upward laminae of pellets and coated grains. The matrix material is welllithified, and many of the bioclasts are dissolved, leaving uncemented or partially cemented molds.

\section{Facies 4 (Bafflestone of Sponge and Algal Structures with a Peloidal and Bioclastic Matrix)}

This facies, found on Allison Guyot (Table 2), consists of a matrix of variable composition between millimeter- to centimeter-sized struc- tures of sponges, encrusting algae, and coral (Fig. 5). The matrix is a loose, clotted micrite that, in some places, is nearly absent as a result of dissolution of larger bioclasts. Unevenly distributed in this matrix are grains, including bioclasts (foraminifers, mollusk fragments, red algae, and echinoids) and micritic grains and lithoclasts. Large (several millimeters), poorly preserved fragments of rudists are common. Red algae form elongate grains and, in many places, encrust mollusk and sponge debris. The micritic particles appear to have a number of origins, but most common are angular mud chips and fecal pellets.

Sponge/algal structures form bulbous masses up to $2 \mathrm{~cm}$ in size with irregular walls of dense micrite and finely crystalline spar. The 


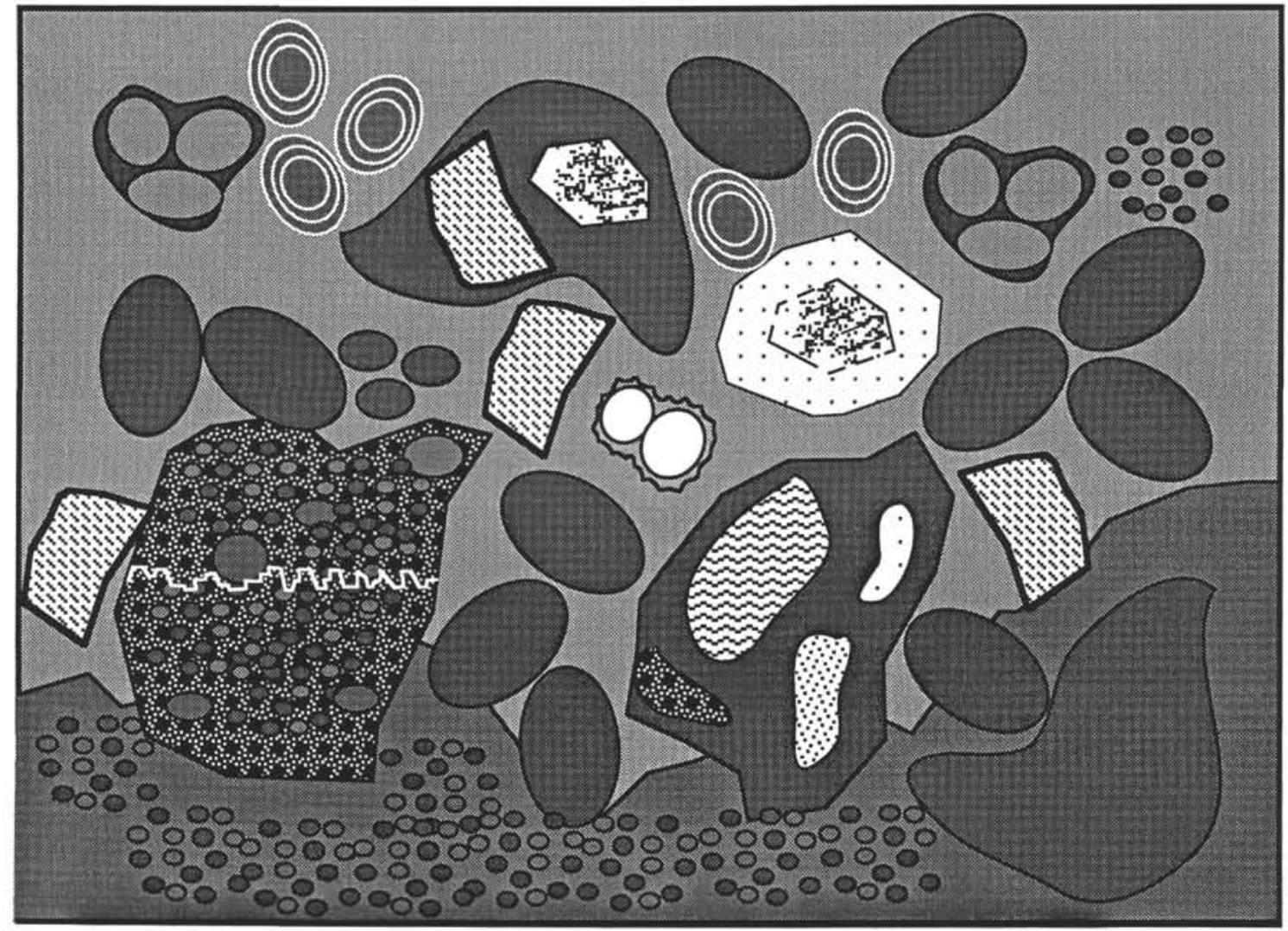

Figure 4. Cartoon representation of Facies 3: Scale and legend as in Figure 2.

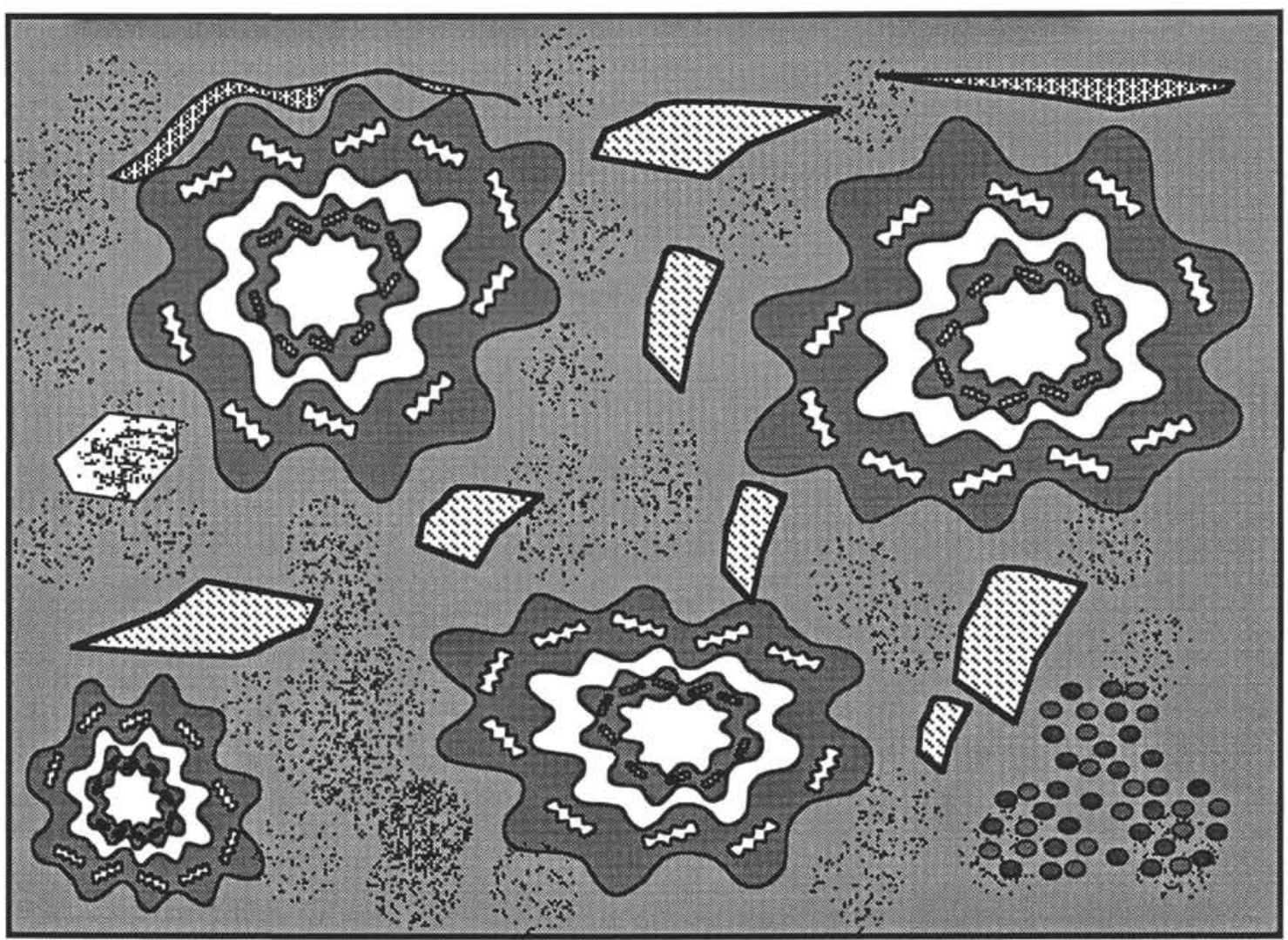

Figure 5. Cartoon representation of Facies 4: Scale and legend as in Figure 2. 
centers of the structures contain imprints of now-dissolved corallites visible in hand specimen. Between the structures is the mud matrix with a variable and irregular distribution of small bioclasts, rudist shells, and micritic particles. Where dissolution of sponge structures and bioclasts has left vugs, micritic particles occur that are loosely connected with micritic cement, indicating possible vadose diagenesis.

\section{Facies 5 (Silicified Oolites)}

Oolite sandstone was dredged from Vibelius Guyot (Table 2). It consists of sand- and coarse sand-sized, tangential, laminated ooids cemented by fringing bladed spar and coarse, blocky spar cements (Fig. 6). Silicification has replaced virtually all the original carbonate material with fine silica that is recrystallizing to small euhedral quartz crystals. Only a few concentric layers of micrite are preserved in the ooids, as well as some of the bladed, fringing sparry calcite cement crystals. No evidence of interstitial mud is found, and the ooids form a packed, grain-supported texture with some fused, interlocking ooid grains, possibly the result of pressure solution.

\section{Facies 6 (Mixed Carbonate and Siliciclastic Sand)}

Shallow-water-derived carbonate clasts are mixed together with volcanic rock fragments and mineral grains (Fig. 7). The dominant carbonate fraction consists of well-rounded, thoroughly micritized bioclasts of algae, bivalve fragments and echinoderm debris, as well as micritic intraclasts and peloids. The volcanic fraction includes mafic lithoclasts, twinned and untwinned feldspars, volcanic glass, and mica. The sand is well sorted and well compacted, and cemented with clayey alteration products. There is no evidence for lamination, bedding or grading.

\section{Facies 7 (Packstone of Peloids with Planktonic Foraminifers)}

This facies, found on Allison Guyot, consists mostly of sand- and fine sand-sized micritic particles in a slightly recrystallized micrite matrix (Fig. 8). Scattered throughout are abundant planktonic foraminifers that form a late Albian assemblage. A second assemblage of planktonic microfossils occurs in small cracks and molds. These are Late Cretaceous to Cenozoic in age. Particles include abundant micritic peloids, micritized benthic foraminifers and poorly preserved mollusk fragments including radiolitid rudists. Many bioclasts were dissolved leaving uncemented molds. Echinoid grains are common, in some places overgrown with syntaxial cement rinds. The matrix is homogeneous and very loosely packed, leaving much intergranular porosity. Minor cementation has occurred, in the form of clear equant spar, that fills some molds as well as most of the intraparticular pores.

\section{Facies 8 (Packstone and Wackestone of Bioclastic Debris in a Lime-mud Matrix)}

This facies, dredged from the northwest side of Allison Guyot (Table 2), consists of fine lime mud with abundant and diverse bioclasts (Fig. 9). Dark granular and tan lime mud form irregularly distributed patches with sharp, irregular shaped boundaries between them. A third, pelletal-granular mud partially fills molds, vugs and cracks. Particles include large, whole gastropod shells and sand- to silt-sized fragments of bivalves, algae, foraminifers, and ostracodes. Most of the bioclasts occur in the tan matrix, along with small mudstone lithoclasts. The mollusk and rare echinoid fragments tend to be poorly preserved and abraded, whereas the foraminifers and green algae are much better preserved.

The large gastropods were completely dissolved and largely replaced with coarse, clear spar cement. Smaller bioclasts including green algae and mollusk fragments were dissolved as well, leaving small molds and solution-enhanced vugs that are partially filled with pelletal mud and clear spar.

\section{DISCUSSION AND CONCLUSIONS}

The samples dredged from the Pacific guyots represent only a fragmented view of carbonate deposition on the mid-Pacific Cretaceous platforms. Nevertheless, each facies described here represents the results of a unique set of circumstances that can be interpreted in terms of sedimentary environments. How these environments are distributed on the platforms cannot be easily known from such a relatively random and sparse sampling. Comparison of the Pacific facies to those described from Cretaceous carbonate platforms elsewhere may allow for a better understanding of the distribution of environments, and the development of a "composite model" of a Cretaceous Pacific mid-oceanic carbonate platform. One model that relates the distribution of facies and depositional environments is shown as a cartoon in Figure 10.

The closest related platforms, both in space and time, are found in Mexico and around the Gulf of Mexico in Texas (Bebout, 1974; Coogan et al., 1972; Freeman-Lynde, 1983; Scott, 1990). An especially good analog is the Valles San Luis Potosi Platform (VSP) in west-central Mexico. This is a rudist-reef-bounded carbonate platform surrounded on all sides by deep marine basins that formed at about the same time as many of the Pacific platforms during Albian to early Cenomanian time. Another series of reefs and platform margins collectively forms the Stuart City Trend (SCT) platform margin in the subsurface of Texas, which is roughly parallel to the presentday coast line of the Gulf of Mexico (Scott, 1990). A variety of depositional environments was identified on these platforms from lithofacies and fossil communities, some of which bear strong resemblance to those found on the Pacific platforms.

Facies 1, the coarse bioclastic grainstone and packstone, is similar to one found in the forereef slope environment of the SCT, where coarse sands of fragments of corals, caprinid, and radiolitid rudists and whole rudist skeletons occur. Unlike the western Pacific platforms, the forereef deposits of the SCT contain significant amounts of coral. The absence of coral fragments in Facies 1 might be an indication that these sediments represent an environment more interior of the platform margin than the SCT deposits, but the dredge locations in which this facies was recovered (upper foreslopes of the platform) suggest otherwise. Likewise, on the VSP, such a rudist grainstone facies is found in the fore-slope environment, where it forms strongly dipping beds that can lie at angles as steep as $43^{\circ}$. Similar steep upper-slope angles were seen in many of the Japanese guyots, where this facies was found in great abundance. On the VSP, similar debris is also part of the reef-core environment, where it fills space between rudist bioherms along the platform margin.

Facies 2 consists primarily of mudstone with small bioclasts, such as miliolid foraminifers, algae, sponge spicules, and ostracodes. Such a lithofacies and fossil association is common in the open-lagoon parts of the SCT, where it is associated with mollusks, echinoids, and red algae. On the VSP, most of the lagoon facies consist of miliolid and peloid sands, with sparse mudstone present only in the most interior, distal portions of the lagoon, where "miliolid micrite" (Scott, 1990) forms one of the lithofacies. It appears that the lagoon-derived facies from the western Pacific platforms represent a more restricted, quietwater environment than was common on the Mexican and Texan platforms. The nerineid gastropods common in Facies 2 are found in interior portions of the SCT as well, generally associated with bivalves and red algae, ostracodes and serpulids (worms), an association that is interpreted as representing a stable environment with a muddy substrate, in the backreef lagoon portions of the platform.

Facies 3, the peloid/ooid/coated-grain assemblage, is well represented in the SCT, where it forms channel-filling sands and shoal areas in environments marginal to the lagoon. On the VSP, peloid-miliolid 


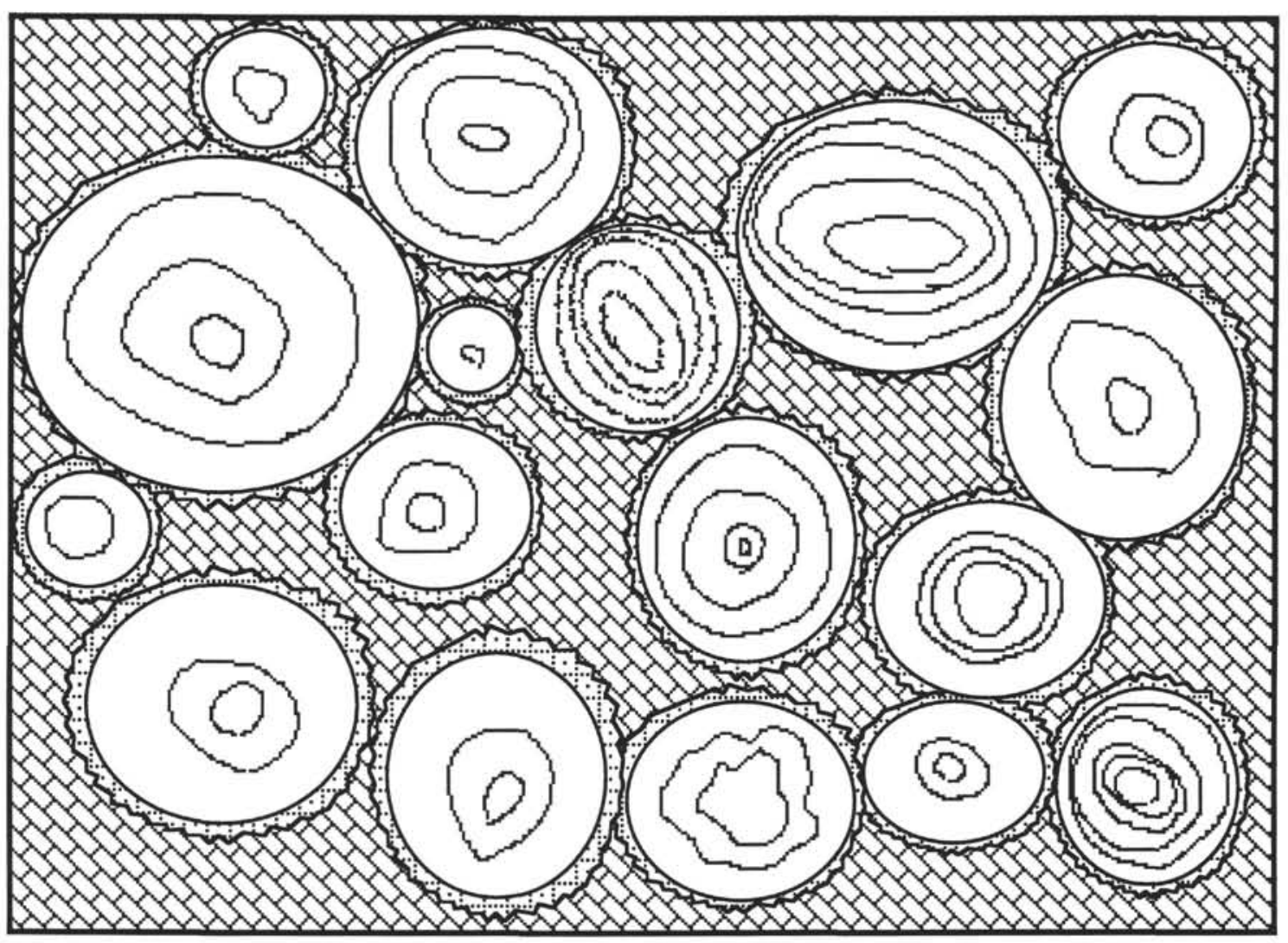

Figure 6. Cartoon representation of Facies 5: Scale and legend as in Figure 2.

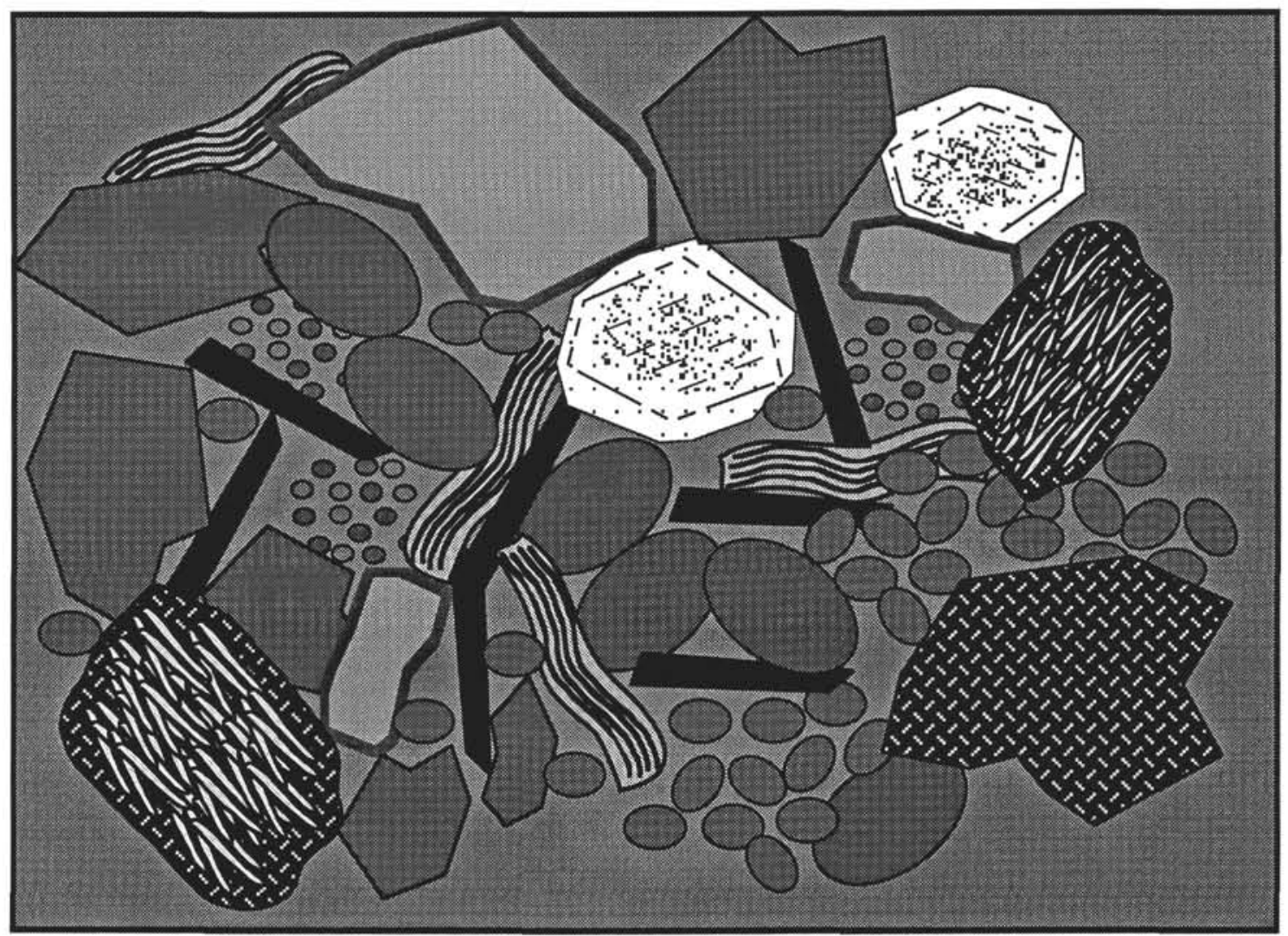

Figure 7. Cartoon representation of Facies 6: Scale and legend as in Figure 2. 


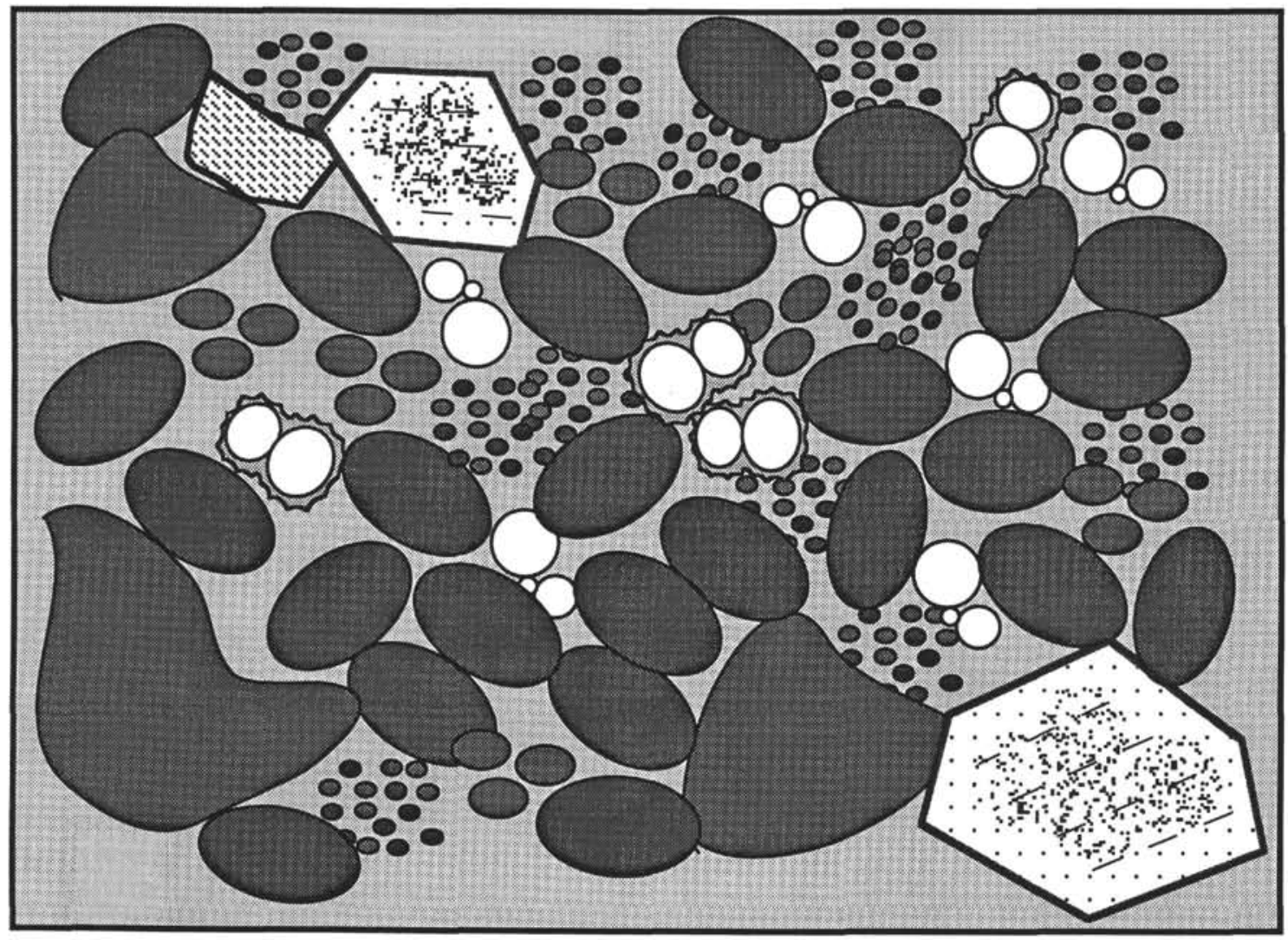

Figure 8. Cartoon representation of Facies 7: Scale and legend as in Figure 2.

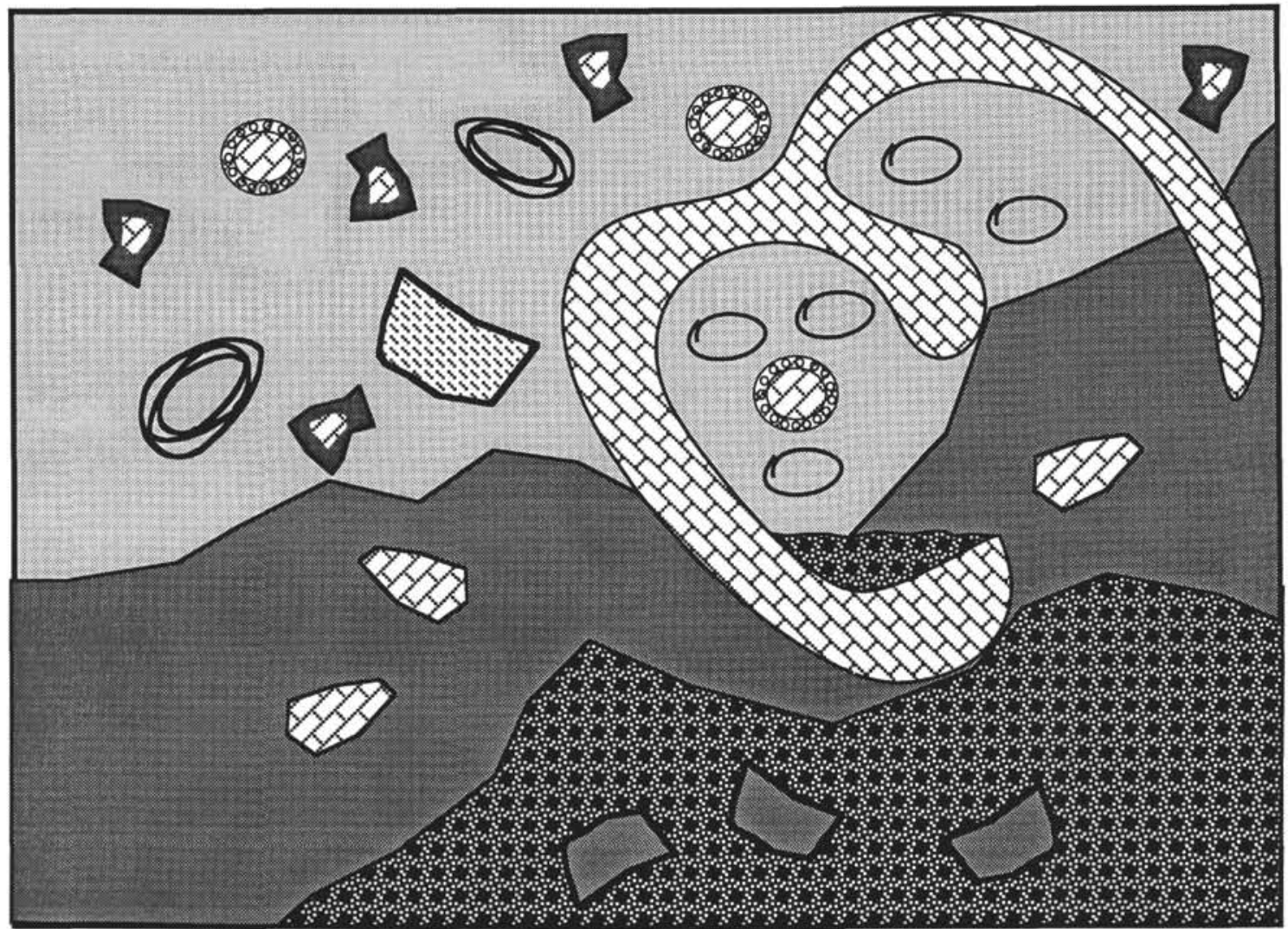

Figure 9. Cartoon representation of Facies 8: Scale and legend as in Figure 2. 


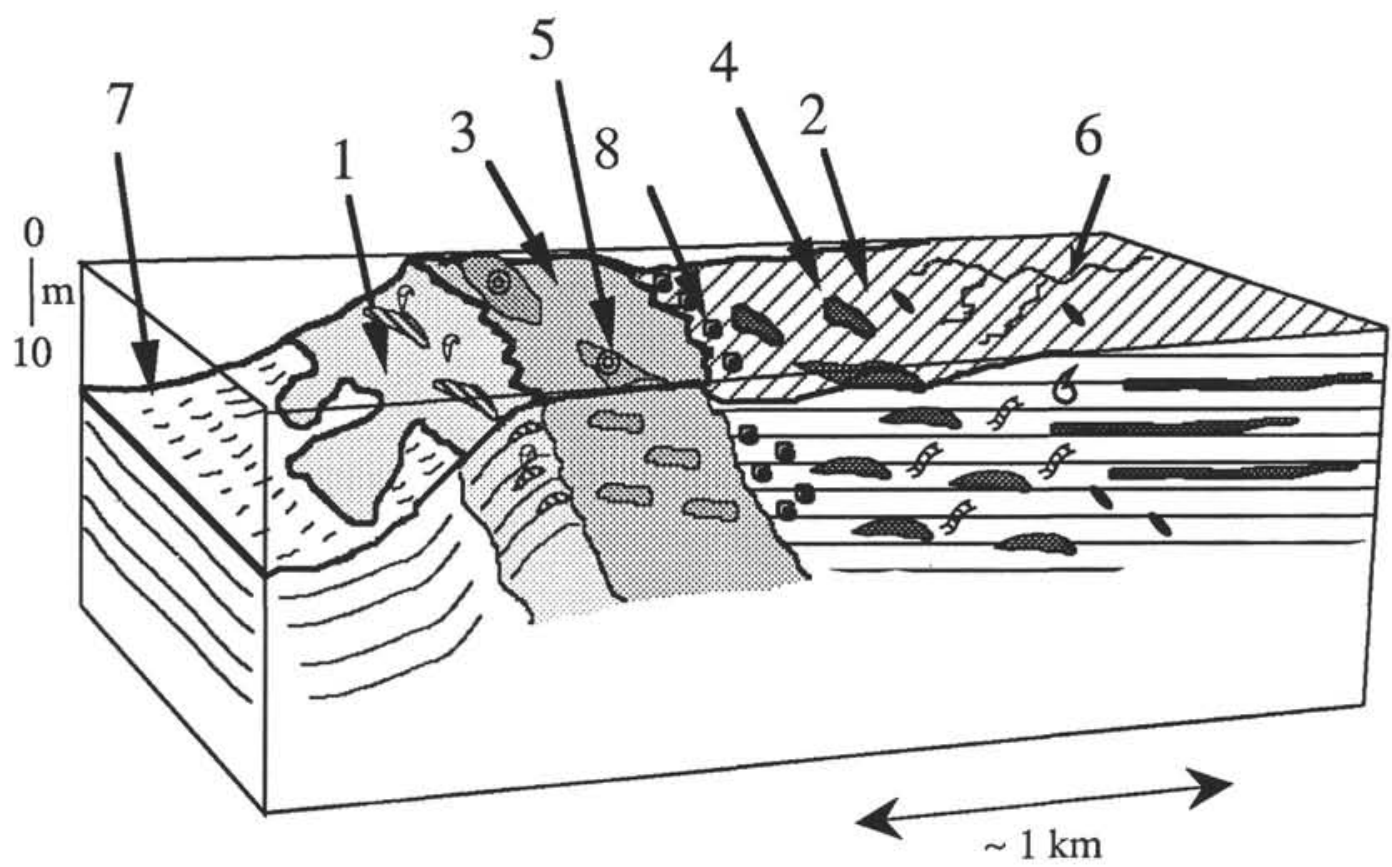

LEGEND

upper slope debris (Facies 1)
$\begin{aligned} & \text { sparse fossiliferous mudstone } \\ & \text { (Facies 2) }\end{aligned}$

Figure 10. Composite model of facies distribution on a Cretaceous Pacific carbonate platform.

packstones form a common backreef facies, where they are associated with reef-derived skeletal debris and intraclasts, and form upwardshallowing sequences (Enos, 1983; Minero, 1983). On these platforms, this facies represents open-marine, backreef/lagoon environments that were relatively energetic and dominated by tidal currents (Enos, 1983). The same facies on the Pacific platforms shows a more variable contribution of reef-derived components relative to lagoonderived components, suggesting that similar, moderately energetic environments were present in various places across the platform.

No obvious analog is described for Facies 4 in either the VSP or the SCT platforms. Shallow bioherms are described in the reef core and marginal backreef environments where coral, red algae, and sponges are common (Scott, 1990). In the samples from Allison
Guyot, the muddy matrix that fills the space between sponge/algal structures consists of fine mud with miliolid and orbitolinid foraminifers, and closely resembles the dominant backreef facies on the VSP platform. This suggests that this facies occupied a similar zone, somewhat inward from the margin, but with fewer contributions from the margin than would be expected in a part of the platform where coral and red algae thrive. The presence of vadose textural features and reworked intraclasts as part of the matrix indicates this was probably a very shallow-water environment that was emergent at times.

Facies 5 , the oolites, is a common high- to moderate-energy facies associated with prograding platform margins (Scott, 1990; Halley et al., 1983). Shoals just interior to the platform margin become dominated by tidal currents that winnow particles to develop peloid sands 


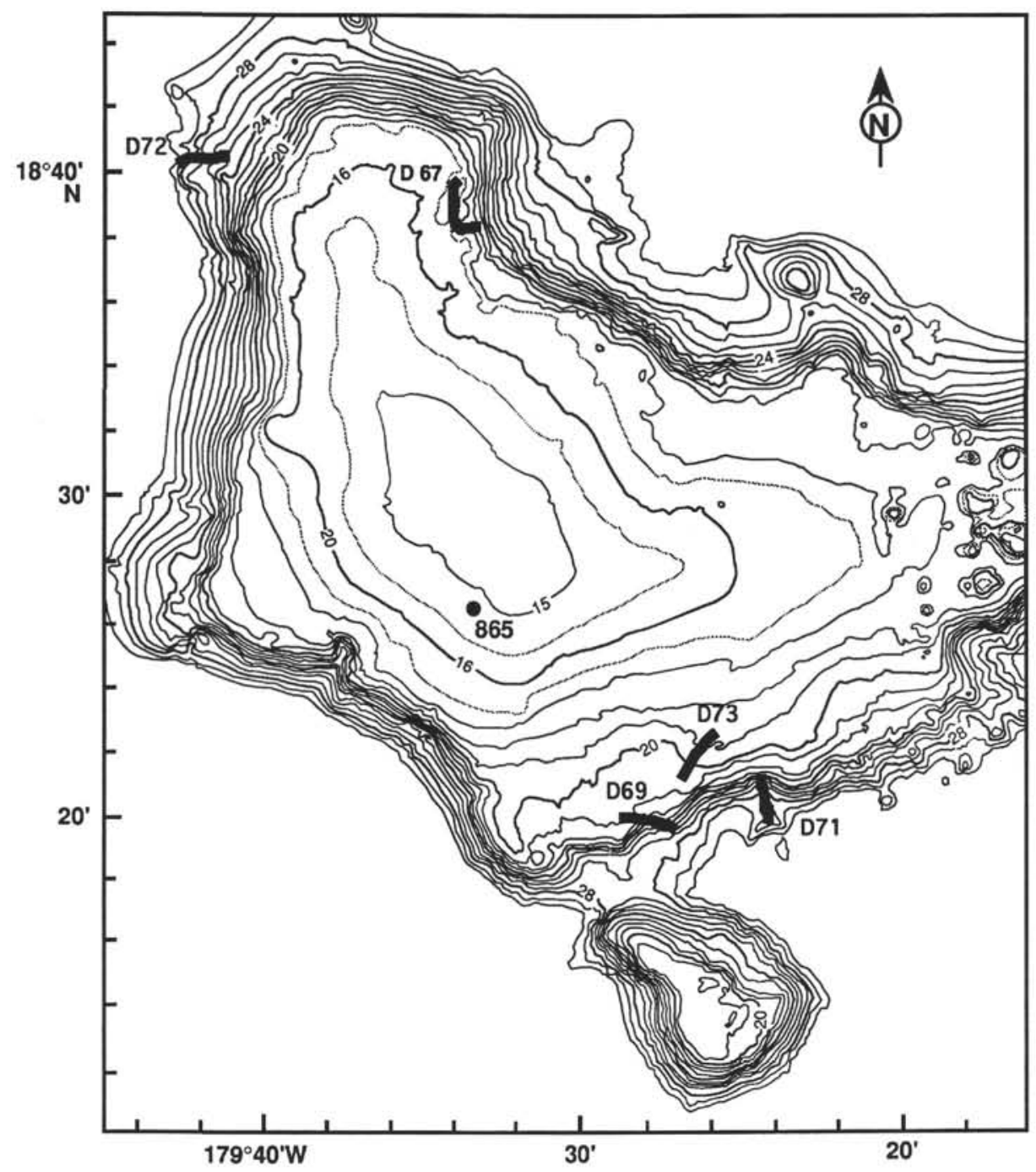

Figure 11. Bathymetry of Allison Guyot from multibeam data. The Roundabout Leg 10 dredge locations for rocks used in this study are indicated by heavy lines. Also shown is the ODP drill site (865).

and, subsequently, ooid sands. These can be swept into tidal bars and even islands and may represent the shallowest parts of the platform. They typically separate the marginal ("reef" and foreslope) from the platform-interior ("backreef" and "lagoonal") environments. On the SCT, ooid-bank facies occur in the reef-flat portions of the Rodessa Formation, which is associated with the SCT platform margin belt. On the VSP, ooid shoals are not common.

The mixed carbonate siliciclastic sediments of Facies 6 are probably specific to a volcanic-island setting, and no analog for this facies occurs in the Mexican or Texan platforms. Textural features suggest that the sand was rapidly transported and deposited, with the carbonate components showing more evidence of reworking and abrasion than the siliciclastic grains. The location of the dredge site (Table 2 and Fig. 11), on the upper slope of Allison Guyot, suggests this may be a beach or shelf-edge sand. The paucity of platform-marginderived components (such as rudist fragments) suggests that the carbonate sands may have been transported by a stream or channel through the interior portion of the platform and quickly deposited on the upper slope without incorporating other grains.

Facies 7 is a mixture of platform-derived and micritized grains and pelagic components and strongly resembles facies associated with both the VSP and SCT platforms. On the VSP platform, facies downslope from the fore-slope deposits include rudist fragments and pelagic microfossils in a micrite matrix. On the SCT platform, wackestones with small bioclasts of mollusks, echinoids, and peloids, and with abundant planktonic microfossils are attributed to a forereef basinal facies. This suggests that Facies 7 represents the deepest of all platform-derived facies and occurs below the coarse bioclastic debris apron, transitional to basinal pelagic facies, in a few tens to hundreds of meters water depth.

Facies 8 is heterogeneous with large whole gastropods in a mud matrix that contains fragments of green and blue-green algae, agglutinated foraminifers, echinoderms, ostracodes, and peloids. Such a diverse assemblage indicates an open-marine environment with a stable, muddy bottom, such as is found in the near-marginal backreef environments on the VSP (Scott, 1990). The site of the dredge in which this facies was recovered, just interior of the outer rim of Allison Guyot (Table 2 and Fig. 11), is consistent with such an interpretation.

A composite model for the distribution of facies and depositional environments, as interpreted from dredged samples, is shown in Figure 10. As this is based on samples from several sites, it is only an approximation of what may have been present on any individual platform in the Cretaceous Pacific. Several aspects stand out. None of the dredged material contained anything resembling a platformmargin, reef-framework facies. Such a facies is characteristic for present-day coral-algal atolls in the Pacific. Furthermore, Scott (1990) 
described the VSP platform as clearly reef-bounded, with in-situ lenticular bodies of coral-rudist buildups acting as frameworks along the edges of the platform. A second interesting aspect is the strong contrast in energy of deposition between the outer-platform/upperslope facies and the platform-interior facies. The latter is composed primarily of fine-grained mudstone. In both the VSP and SCT platforms, the platform-interior environments are dominated by sandy peloid/foraminifer packstone and grainstone and show a clear gradient of depositional energy over many kilometers into the platform interior. Especially on the VSP, true mudstone is relatively rare. On the Pacific platforms, energy of deposition dropped from high on the margins and uppermost slopes to very low immediately interior to the margin, so that most of the platform interior was exceedingly muddy. Drilling on Allison and Resolution guyots during Leg 143 showed a great abundance of sediments that matched Facies 2 (Shipboard Scientific Party, 1993a, 1993b) in the upper parts of the sections recovered on these sites. This implies that, although there are no signs of reef structures or other firm barriers, damping of wave energy at the margins was efficient. Very little coral was found in the dredge material. One explanation for this is that the Pacific was truly "pacific" and did not subject the mid-oceanic platforms to particularly energetic conditions. During the middle Cretaceous, the platforms were thought to be located in the tropical Pacific Ocean (Sager, 1992). Platforms such as the VSP were clearly subjected to storms and other conditions of strong energy, the effects of which are noticeable in the sedimentary facies for many kilometers into the platforms. There is no reason to assume that the open ocean was exempt from such conditions. Another possibility is that the platform margin efficiently dampened wave energy by having little depositional relief (Enos, 1983). In absence of other forces, the mid-oceanic tidal range may have allowed the bank tops to build near (1-2 m) sea level, and in many places, intertidal conditions may have prevailed, preventing wave energy from reaching very far beyond the margins. Sediments at the margins, which contained a large percentage of aragonite in the form of mollusk shells, were subject to rapid lithification during early diagenesis, which stabilized the platform margins and prevented substantial wave erosion during the upward growth of the platforms. Textural evidence of early cementation of the mollusk grainstones would support this possibility.

In summary, from petrographic analyses of dredged limestone samples, western Pacific Cretaceous carbonate platforms developed into shallow, exceedingly muddy banks. These were held together, not by reef structures, but by rapid lithification of sediment during early diagenesis. The platform-interior environments were protected from storms and ocean waves by the damping effects of shallow water.

\section{ACKNOWLEDGMENTS}

The author gratefully acknowledges I. Premoli Silva and B. Sliter for their patient help with identification of microfossils, and E.L. Winterer for overall guidance and support. Some of the figures were made using software developed by P. Wessel and W.H.F. Smith. The work was partly supported by the JOI-USSAC post-cruise science support program and by NSF Grant 8717079 -OCE.

\section{REFERENCES}

Aguayo, J.E.C., 1976. Sedimentary environments and diagenesis of El Abra Limestone at its type locality, eastern Mexico. AAPG Bull., 60:644.

Bathurst, R.G.C., 1965. Boring algae, micrite envelopes and lithification of molluscan biosparites. Geol. J., 5:15-32.

\footnotetext{
Abbreviations for names of organizations and publications in ODP reference lists follow the style given in Chemical Abstracts Service Source Index (published by American Chemical Society).
}

Bebout, D.G., 1974. Lower Cretaceous Stuart City shelf margin of South Texas: its depositional and diagenetic environments and their relationship to porosity. Trans. Gulf Coast Assoc. Geol. Soc., 24:138-159.

Carannante, G., Esteban, M., Milliman, J.D., and Simone, L., 1988. Carbonate lithofacies as paleolatitude indicators: problems and limitations. Sediment. Geol., 60:333-346.

Coogan, A.H., Bebout, D.G., and Maggio, C., 1972. Depositional environments and geologic history of Golden Lane and Poza Rica Trend, Mexico: an alternative view. AAPG Bull., 56:1419-1447.

Enos, P., 1983. Shelf environment. In Scholle, P.A., Bebout, D.G., and Moore, C.H. (Eds.), Carbonate Depositional Environments. AAPG Mem., 33:267-295.

Flügel, E., 1982. Microfacies Analysis of Limestones: New York (SpringerVerlag).

Freeman-Lynde, R.P., 1983. Cretaceous and Tertiary samples dredged from the Florida Escarpment, eastern Gulf of Mexico. Trans. Gulf Coast Assoc. Geol. Soc., 33:91-99.

Grötsch, J., 1991. Die Evolution von Karbonatplatformen des offenen Ozeans in der mittleren Kreide (NW-Jugoslawien, NW-Pazifik, NW-Griechenland): Möglichkeiten zur Rekonstruktion von Meeresspiegelvarenderungen verschiedener Groszenordnung [Ph.D dissert.]. Inst. Paleontol. Univ. Erlangen, Neurenberg, Germany.

Halley, R.B., Harris, P.M., and Hine, A.C., 1983. Bank margin environment. In Scholle, P.A., Bebout, D.G., and Moore, C.H. (Eds.), Carbonate Depositional Environments. AAPG Mem., 33:463-506.

Hamilton, E.L., 1956. Sunken islands of the Mid-Pacific Mountains. Mem.Geol. Soc. Am., 64.

Heezen, B.C., Matthews, J.L., Catalano, R., Natland, J., Coogan, A., Tharp, M., and Rawson, M., 1973. Western Pacific guyots. In Heezen, B.C. MacGregor, I.D., et al., Init. Repts. DSDP, 20: Washington (U.S. Govt. Printing Office), 653-723.

Hess, H.H., 1946. Drowned ancient islands of the Pacific basin. Am. J. Sci., 244:772-791.

Ladd, H.S., Newman, W.A., and Sohl, N.F., 1974. Darwin Guyot, the Pacific's oldest atoll. Proc. 2nd. Int. Coral Reef Symp., 2:513-522.

Menard, H.W., 1964. Marine Geology of the Pacific: New York (McGrawHill).

Minero, C.J., 1983. Sedimentation and diagenesis along open and island-protected windward carbonate platform margins of the Cretaceous El Abra Formation, Mexico. Sediment. Geol., 71:261-288.

Sager, W.W., 1992. Seamount age estimates from paleomagnetism and their implications for the history of volcanism on the Pacific Plate. In Keating, B.H., and Bolton, B. (Eds.), Geology and Offshore Mineral Resources of the Central Pacific Basin. Circum.-Pac. Counc. Energy Miner. Resour., Earth Sci. Ser., 14:21-37.

Sager, W.W., Winterer, E.L., Firth, J.V., et al., 1993. Proc. ODP, Init. Repts., 143: College Station, TX (Ocean Drilling Program).

Sartorio, D., and Venturini, S., 1988. Southern Tethys Biofacies: Milan (AGIP).

Schlanger, S.O., 1964. Petrology of the limestones of Guam. Geol. Surv. Prof. Pap. U.S., 403-D:1-52.

Scott, R.W., 1990. Models and stratigraphy of Mid-Cretaceous reef communities, Gulf of Mexico. Soc. Sediment. Geol., Concepts Sedimentol. Paleontol., 2.

Shipboard Scientific Party, 1993a. Site 865. In Sager, W.W., Winterer, E.L., Firth, J.V., et al., Proc. ODP, Init. Repts., 143: College Station, TX (Ocean Drilling Program), 111-180.

, 1993b. Site 866. In Sager, W.W., Winterer, E.L., Firth, J.V., et al., Proc. ODP, Init. Repts., 143: College Station, TX (Ocean Drilling Program), 181-271.

van Waasbergen, R.J., 1993. Western Pacific guyots: summit geomorphology, sedimentology and structure of Cretaceous drowned carbonate platforms [Ph.D. dissert.]. Univ. of California San Diego, La Jolla, CA.

van Waasbergen, R.J., and Winterer, E.L., 1993. Summit geomorphology of Western Pacific guyots. In Pringle, M.S., Sager, W.W., Sliter, W.V., and Stein, S. (Eds.), The Mesozoic Pacific: Geology, Tectonics, and Volcanism. Geophys. Monogr., Am. Geophys. Union, 77:335-366.

Wilson, J.L., 1975. Carbonate Facies in Geologic History: New York (Springer-Verlag).

Winterer, E.L., and Metzler, C.V., 1984. Origin and subsidence of guyots in the Mid-Pacific Mountains. J. Geophys. Res., 89:9969-9979,

Winterer, E.L., Natland, J.H., van Waasbergen, R.J., Duncan, R.A., McNutt, M.K., Wolfe, C.J., Premoli Silva, I., Sager, W.W., and Sliter, W.V., 1993. Cretaceous guyots in the Northwest Pacific: an overview of their geology 
and geophysics. In Pringle, M.S., Sager, W.W., Sliter, W.V., and Stein, S. (Eds.), The Mesozoic Pacific: Geology, Tectonics, and Volcanism. Geophys. Monogr., Am. Geophys. Union, 77:307-334.

Date of initial receipt: 1 December 1993

Date of acceptance: 21 June 1994

Ms 143SR-242

\section{APPENDIX}

\section{Detailed Descriptions of Carbonate Facies}

This appendix contains detailed observations and descriptions of each facies, generally organized by particles, matrix composition, texture, diagenesis, and an interpretation of the environment of deposition. The dredge locations for samples collected during the Roundabout Expedition (Leg 10) are tabulated in Table 2. Dredge locations for the Aries Expedition (Leg 5) are given in Heezen et al. (1973).

\section{Facies 1 (Coarse Bioclastic Grainstone and Packstone)}

This facies is characterized by abundant coarse skeletal debris of mollusks (predominantly rudists, but including abundant gastropods and common neritic bivalves such as Inoceramus), red algae, echinoids, and, to lesser extent, benthic foraminifers and limestone rock fragments, which are loosely to completely cemented together by fringing, bladed and syntaxial calcite cement. It is by far the most common nonphosphatized type of shallow water and shallow waterderived limestone dredged from the western Pacific guyots.

\section{Particles}

Grains are typically angular, partially micritized bioclasts, which are very poorly preserved, although in most samples mollusk microstructures were preserved in certain grains. Mollusk fragments $(80 \%)$ include fragments of thick-shelled rudist bivalves, mainly from massively walled caprinids. Some fragments show the two-layer structure of radiolitids. The outer layer of these, originally aragonite, has been dissolved away except for a thin micritized rind. The thicker inner layer of low-magnesium calcite is preserved with recognizable lamellar and crossed-lamellar microstructure. Fragments of Inoceramus can be recognized by the typical prismatic crystal structure of the shell.

Fragments of various types of algae occur $(10 \%)$ among which a massive, often poorly preserved form of red algae is the most common. This form is characterized by a microstructure of fine radial, nonbifurcating tubules approximately $50 \mu$ in diameter, that are generally preserved as cast structures: the tubules are filled with micrite, whereas the surrounding skeletal material of the calcareous algae has been replaced by finely crystalline spar (Fig. A1). Clasts of this algal material can be up to several $\mathrm{cm}$ in diameter, but are generally sand- to coarse sand-sized.

Other forms of algae include Cayeuxia, a blue-green algae that is characterized by closely packed, bifurcating micritic tubules, and Polystrata alba (Fig. A2), a member of the red algae group Squamaraceae. Numerous sandsized micritic particles with poorly defined internal structures may likewise be algal in origin, but are too poorly preserved to be identified as such with certainty. Some of the grains that appear to be micritic in thin section may in fact be sections through a micritic rind at the edges of grains. They occur commonly as smaller grains in pockets between larger, more readily identifiable skeletal fragments.

Fragments of echinoderms are common (5\%), generally in the form of equant and prismatic angular grains, which behave optically as single crystals of calcite. They most likely originated from echinoids (sea urchins), because this facies occurs commonly in association with well-preserved thick clubshaped spines of cideroid urchins.

Other constituents (5\%) include benthic and planktonic foraminifers, bryozoa, limestone rock fragments, and very rare coral fragments. Many samples contain common lithoclasts of wackestone and packstone. These grains can be distinguished from ordinary grains by the occurrence of broken fossil-fragments and discontinuous cement-rinds at the grain-boundaries. Coated grains are rare, except in samples from "Thomas Washington" Guyot. The micritic outer walls of most grains are clearly produced by micritization of the shell walls, rather than by coating with mud. This may be interpreted as indicative of deposition under high-energy condition of short duration or temporary nature, such as a channel-or storm-deposit.

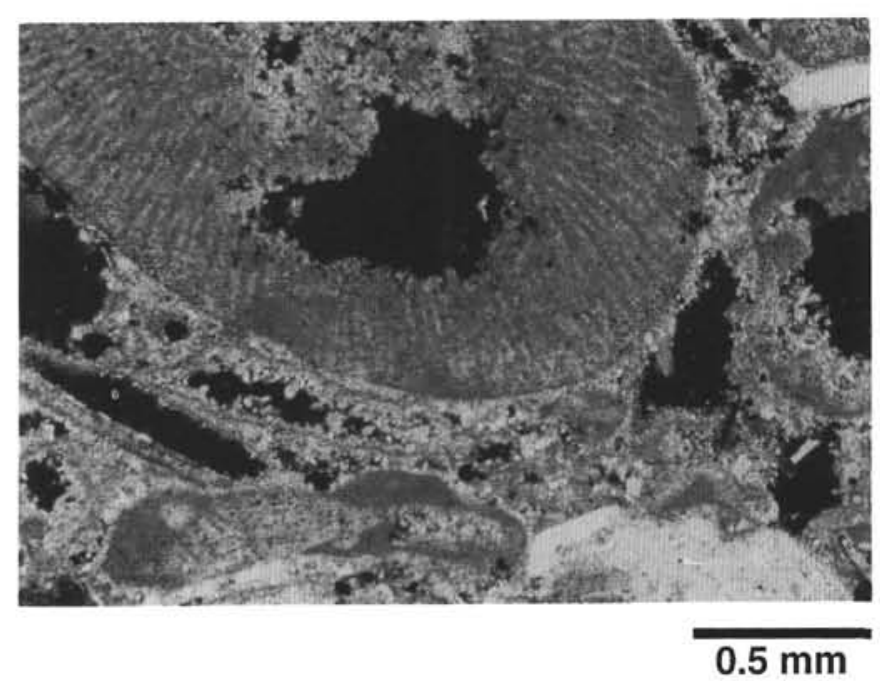

Figure Al. Photomicrograph of skeletal grainstone (Facies 1). The large, rounded grain in upper left part of the photograph is a fragment of solenoporan red algae. The other grains are fragments of mollusks and echinoids, all partially cemented by equant spar cement (calcite). Sample RNDB-D53-1.

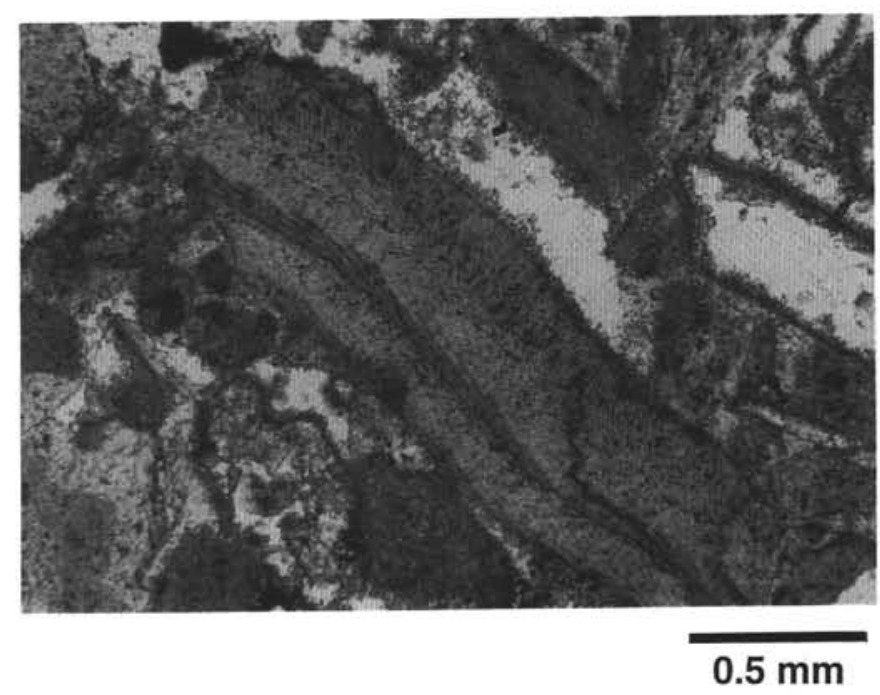

Figure A2. Photomicrograph of skeletal grainstone (Facies 1). The elongate grain (center) is a fragment of the squamaracian red algae Polystrata alba. Other grains include poorly preserved fragments of mollusks and echinoderms, and rounded micritic grains (peloids). Sample A5-31-A12.

\section{Texture}

Grainstone and packstone textures predominate. In samples with a muddy matrix (packstones) the matrix is commonly partially to completely phosphatized. In the most phosphatized samples, only echinoid fragments remain as calcite particles; other particles have been reduced to molds in a finely crystalline phosphatic matrix.

In nonphosphatized and partially phosphatized samples of this facies, grains are fine sand to gravel in size, poorly sorted, and with no noticeable grading or bedding. Imbricate textures, which indicate deposition in a strong current, occur in samples from Resolution Guyot (RNDB-D65). Little evidence for compaction can be seen. Few examples were seen of collapsed molds, which typically result from compaction after early partial dissolution of grains. In packstones, the muddy matrix consists of micrite of variable density that fills all interparticular space, as well as some moldic porosity. In many samples, the interstitial micrite appears in the form of small pellets that 


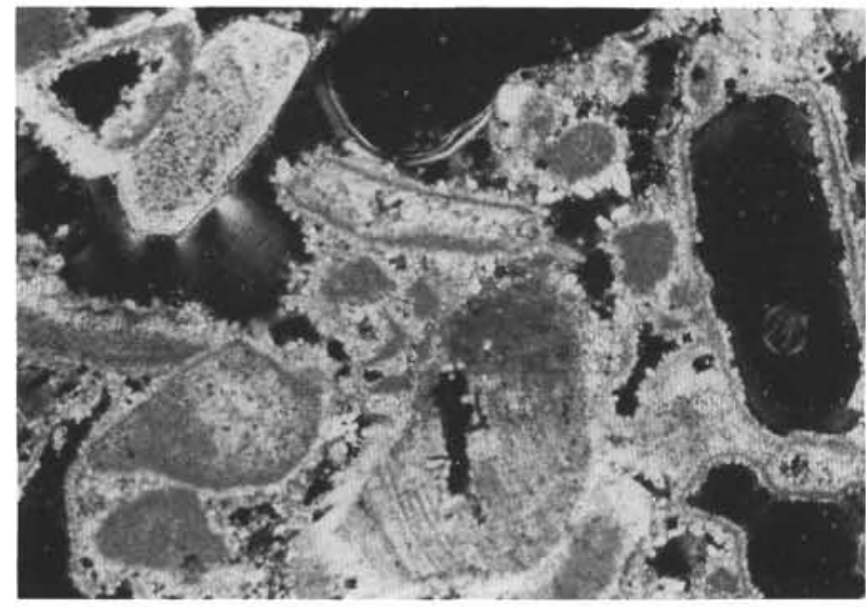

$0.5 \mathrm{~mm}$

Figure A3, Photomicrograph of skeletal grainstone (Facies 1). Grains include poorly preserved bioclasts of mollusks, algae and echinoderms, loosely cemented with equant and bladed spar cement. Echinoid fragments are characterized by syntaxial diagenetic overgrowths. Mollusk fragments remain only as micritic envelopes. Sample RNDB-D53-1.

commonly fill both mollusk molds and intergranular space, but that postdate the earliest generation of cement.

Biota

Most of the grains appear to be fragments of rudists, both caprinids and radiolitids. Other common skeletal fragments include gastropods, solenoporacean (red) algae, and coralline (red) algae. Less common constituents are benthic foraminifers, rare planktonic foraminifers (not identifiable), green algae (Woods Hole Guyot), and red algae belonging to the group Squamaracia, possibly Polystrata alba, as well as Lithocodium cf. aggregatum.

Some samples of packstone were studied by Scanning Electron Microscope (SEM) to search for nannofossils in the muddy matrix, but none were found (T. Bralower, pers. comm., 1990).

\section{Diagenesis}

The grains were rapidly cemented with fine-bladed spar cement during diagenesis, which preceded the dissolution of mollusk grains. Most of the mollusk fragments are recognizable only as micritic envelopes, partially to completely filled with bladed and blocky spar cement (Fig. A3). These micritic envelopes originate from the destruction of the outermost part of the original shell fragment by microscopic organisms (Bathurst, 1965). Micritic calcite cement precipitates in these holes. This process occurs during deposition, while the grain is still at the sediment surface. The micrite envelope is generally more resistant to dissolution than is the original shell, so that ultimately only the envelope remains, after the rest of the shell dissolves. Following dissolution of the shell, the molds and the remaining pore space were partially filled with coarse blocky spar cement. In some places, interstitial mud infiltrated the rocks, but this generally postdated early cementation.

In samples with little to no interstitial mud, echinoid fragments have characteristic syntaxial overgrowths: the grains are enlarged with optically continuous calcite cement. In packstones, the echinoid debris commonly occurs without cement, and may even be partially micritized. Syntaxial cements appear to have formed preferentially on nonmicritized parts of the echinoid grains.

\section{Interpretations}

Material of peri-reefal origin, including large whole rudist specimens, predominates, whereas lagoon-derived clasts (mudstones, sponge-debris, highspired gastropods) are notably absent. Coral-debris is also very rare, possibly owing to the low preservation potential of the aragonitic coral skeletons. Size

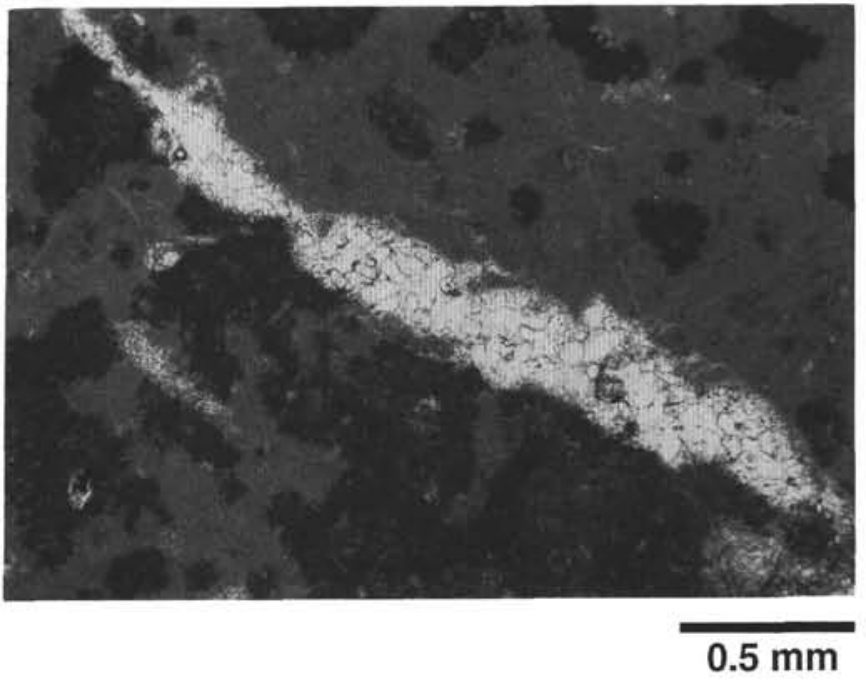

Figure A4. Photomicrograph of sparse fossiliferous mudstone (Facies 2). Two forms of matrix mud are irregularly distributed throughout: a dominant, light-colored micrite, and a darker, more granular micrite. Sample RNDBD56-15.

ranges, lack of sorting, and occurrence of imbricate structures suggest deposition under conditions of high energy, possibly in strong currents. The lack of coating of grains, grain-angularity and common occurrence of postdepositional infiltration of lime mud suggest that the high-energy conditions were intermittent or of short duration.

The texture and constituents of this facies closely resemble those found at the very top and outer slope of the platform-margin deposits of the Tamabra limestone formation in west-central Mexico (Aguayo, 1976). There, coarse bioclastic grainstones and packstones form the final transgressive layer marking the end of deposition on the shallow platform, and commonly occur as talus blocks on the upper slope of the platform (Enos, 1983).

\section{Facies 2 (Mudstone, Fossiliferous Mudstone and Wackestone)}

This facies is characterized by a predominance of a lime-mud matrix, in which bioclasts of benthic foraminifers, algae, sponge spicules, and ostracode tests occur in varying abundances, and large nerineid gastropods are common.

\section{Matrix}

The matrix consists of well-lithified lime mud of very fine grain size (micrite). Variability in color and granularity is common within single thin sections: darker patches of micrite $0.5 \mathrm{~mm}-5 \mathrm{~mm}$ in size occur within the more abundant lighter micrite, with irregular boundaries. In hand specimens the "dark" matrix is actually whiter than the surrounding tan (light) matrix The darker micrite appears to be slightly more granular (Fig. A4). It consists of small clots $\pm 20 \mu \mathrm{m}$ in diameter that contain submicrometer-size specks of opaque material. In reflected light these are metallic yellow and may be pyrite. The micrite crystals themselves are $0.1-0.4 \mu \mathrm{m}$ in size. These two types of matrix will be referred to as "tan" (the lighter, homogeneous, more abundant matrix) and "granular" (the darker matrix associated with pyrite).

The tan micrite also has a clotted fabric, with individual clots typically $50-75 \mu \mathrm{m}$ in diameter and far less well developed than in the granular micrite. In some samples, small $(50-100 \mu)$ opaque dendritic structures occur that are probably manganese-oxide replacements of the original limestone. The granular patches yield slightly lighter $\delta^{13} \mathrm{C}$ values than do the tan micrite (van Waasbergen, 1993). This may indicate a slightly higher content of organicderived carbon in the calcite in the granular micrite. The apparent association between granular micrite and the occurrence of pyrite may indicate that the granular patches represent originally more organic-rich parts of the sediment. The highly irregularly shaped boundaries between the patches of granular micrite and the surrounding tan micrite suggest that this distribution is the result of incomplete mixing of originally layered sediment, most likely by bioturbation before lithification of the sediment. Evidence of bioturbation can 
be seen in rare recognizable tubular burrows and in sheltered areas such as the insides of gastropods, where the micrite occurs as ovoid fecal pellets 0.5 to 1 $\mathrm{mm}$ in diameter.

\section{Particles}

Particles in this facies consist exclusively of bioclasts, recrystallized bioclasts, and molds of bioclastic material. For the purpose of understanding the original sediment composition, the molds will be treated as particles as far as they can be identified. Bioclasts and molds of foraminifers, ostracodes, mollusks, spicules, algae, and pellets occur in variable amounts and relative abundances. Bioclasts range in size from $0.1 \mathrm{~mm}$ to $2 \mathrm{~mm}$. The origin of fragments smaller than $0.1 \mathrm{~mm}$ cannot be determined.

Foraminifers are predominantly small (up to $\pm 0.5 \mathrm{~mm}$ ) agglutinated forms including biserial Cuneolina, Textularia, rare planispiral forms, and some miliolids. Only a few planktonic foraminifers have been reported (Grötsch, 1991) and were not observed in these samples. The benthic foraminiferal tests are generally composed of recrystallized micrite identical in composition to that of the matrix (Fig. A5). Foraminiferal chambers are filled with fine equant spar. Most of the tests appear to be complete, rather than fragmented. Most of the small round molds that are common in most samples can probably be attributed to dissolved foraminiferal tests. Miliolid tests are more commonly preserved as a slightly darker, denser micrite, and contrast well with the surrounding matrix. The abundance of foraminifers varies between samples. Cuneolina-types appear to be more common in the samples from MIT Guyot, whereas those from Allison Guyot contain more miliolids.

Ostracode tests are common in the samples from Allison Guyot, less so in those from MIT Guyot. The tests are up to $0.5 \mathrm{~mm}$ long, a few tens of micrometers thick, and most commonly found in disarticulated form. They retain their characteristic prismatic microstructure, indicated by a "sweeping extinction" pattern under crossed nichols.

Two types of algae were observed in this facies: a very poorly preserved massive-branching form similar to Cayeuxia, and fragments of Dasycladacea (green algae). Algal structures are commonly filled with clear equant spar, whereas the wall structures are micritic, or completely absent. In the latter case, they remain unfilled by cement or sediment.

Fragments of bivalves occur in most samples, and range in size from fine sand to coarse sand. These fragments are typically very poorly preserved and show signs of abrasion by transport and by biological processes: most grains have irregular, notched and serrated edges, and are micritized and bored. The original shell-wall structure is preserved as ghostly micritic bands in otherwise clear crystalline calcite. Many of the bivalve fragments have a two-layer structure: a thin layer on the convex, outer side of the slightly curved fragments consists of clear prismatic spar, whereas the thicker inside layer consists of coarse spar in which an original crossed-lamellar growth structure is visible.

Gastropod remains are present in two main forms: small, thin-shelled, low-spired forms and large, thick-shelled, ornamented, high-spired forms. Debris from the thin-shelled forms occurs as recrystallized shells and shel fragments and as mud- or spar-filled molds, all of which are from broken-up debris, rather than from whole shells. The large, thick-shelled nerineid gastropod shells also are not preserved, but replaced with blocky spar cement. The original shell wall was dissolved, and fringing and drusy-mosaic spar is in its place. Some samples lack this secondary cement, leaving only empty molds in which lithified mud that had filled the shell at time of deposition remains as a loose cast. On MIT Guyot such loose casts from the insides of nerineid gastropods were very abundant. The chambers of the gastropod shells are generally filled with pelletal mud identical to that surrounding the shells. Most shell walls are micritized, leaving a thin micritic rind between the matrix and the mold-filling spar cement. This indicates that the large nerineid shells were abandoned, the outer shell walls micritized, and the shell cavities filled with mud. The mud became lithified, and dissolution removed the original aragonitic shell wall, leaving a mold that became, in some places, filled with clear fringing and equant spar cement. Lithification of the surrounding and interior mud preceded dissolution, or the space left by the dissolved shell-wall would have been filled with mud.

Many samples contain thin spicules up to $2 \mathrm{~mm}$ in length. These generally are recrystallized to clear spar cement (Fig. A6). The spicules are straight, tapered in longitudinal section and circular in transverse section. Some of the thicker spicules appear to have micritic cores, indicating they were originally hollow. These are likely sponge spicules.

Round and oval fecal pellets, $0.25-0.5 \mathrm{~mm}$ in diameter, are common in uncompacted burrows. They consist of micrite and small particles, identical in appearance to the surrounding matrix. Where occurring in burrows, the pellets are cemented by clear crystalline spar, indicating that burrowing occurred in fairly well-lithified sediment, and that burrows did not refill with mud.

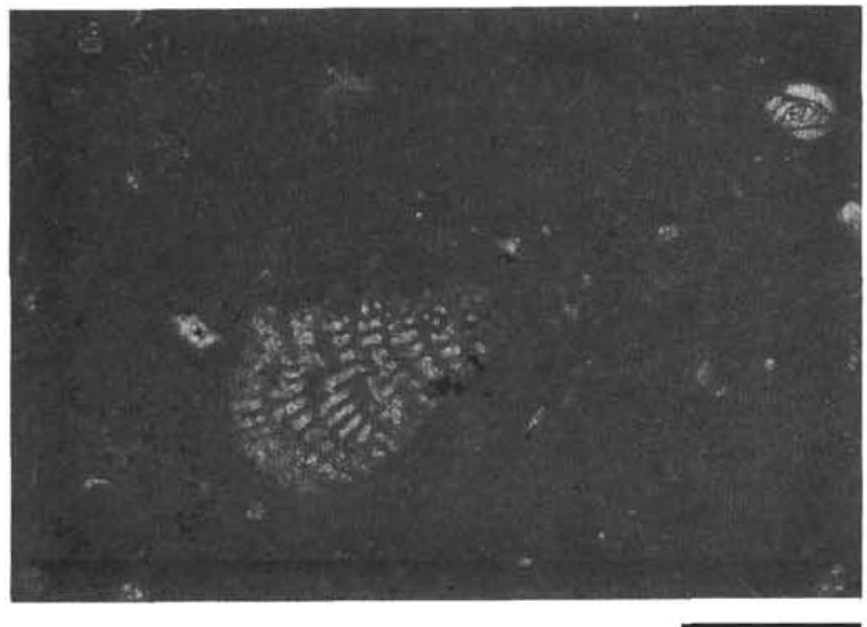

$0.5 \mathrm{~mm}$

Figure A5. Photomicrograph of sparse fossiliferous mudstone (Facies 2). Tan micrite matrix contains agglutinated benthic foraminifers and sponge spicules. The larger, cone shaped foraminifer is Cuneolina sp., a miliolid. Sample RNDB-D56-29-R1.

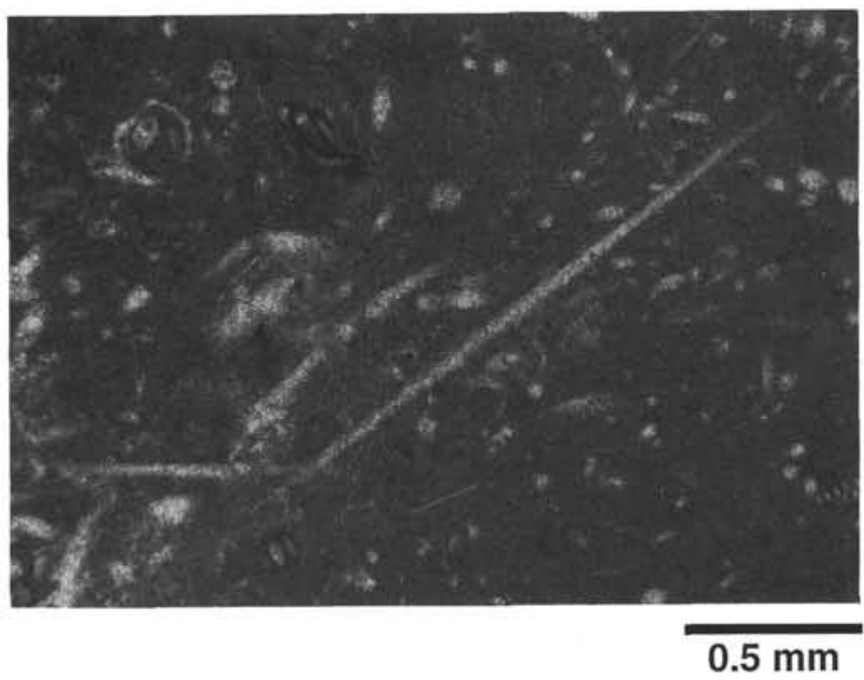

Figure A6. Photomicrograph of fossiliferous mudstone (Facies 2). Homogeneous tan matrix with abundant, calcareous spicules. Sample RNDB-D56-28.

Small equant crystalline fragments of miscellaneous unidentifiable debris are common in most samples of this facies. These may represent bits of bioclasts too small to be identified. No ooids, intraclasts, or lithoclasts were recognized.

\section{Texture}

The texture of this facies varies between sparse fossiliferous micrite (1\%-10\% particles) and sparse biomicrite (more than $10 \%$ particles, but mud-supported). The original primary porosity was probably high, in the form of intercrystalline "microporosity" of the unlithified mud, but has been reduced upon lithification and compaction. Such mud-porosity can be more than $35 \%$ (Flügel, 1982). Other primary porosity included the intragranular spaces, such as foraminiferal spaces and the perforations of algal fragments. Rare articulated ostracodes remain unfilled. The current porosity is $15 \%-40 \%$ (determined by visual estimates of hand specimens as well as thin sections) and largely moldic. Some molds appear to have been slightly enlarged by dissolution, whereas others are partially to completely occluded with spar cement. 


\section{Structures}

Sorting, bedding, or lamination is not evident in samples cut for thin sections. Patchily distributed dark-granular mud may indicate some original bedding that was disturbed by bioturbation. Incomplete mixing by bioturbation also resulted in patchy distribution of the various types of bioclasts. Hence, bioclasts of any particular type now tend to occur concentrated in $1-3 \mathrm{~mm}$ areas of a thin section. Sample RNDB10-D56-28 (MIT Guyot) contains curious elongate, subparallel or radially oriented filamentous strings of calcite that resemble calcified rootlets.

Many of the samples also contain fractures that appear to cross both types of matrix and cement-filled molds, indicating the fractures formed at a late stage in the diagenetic history. Most of the fractures are filled with clear, equant spar, although some are wholly or partially filled with mud and small mud clasts (Fig. A7). Parts of molds and bioclasts appear to be slightly offset across the fractures, indicating these are extensional cracks, rather than openings caused by solution, although they may have been enlarged by solution.

\section{Diagenetic History}

The diagenetic events and processes that have affected the rocks of this facies appear to include the following:

1. Lithification of bioturbated mud occurred at an early stage, with very little compaction. Tubular structures and patchy matrix inhomogeneities remain unflattened, leaving a firm, micritic texture.

2. Dissolution of bioclasts occurred after lithification, because all molds appear to be undeformed, and none appear to have collapsed. This process may have coincided with nondestructive recrystallization of some original shell materials, including originally calcitic parts of bivalve fragments and the thin shell walls of some gastropods, ostracodes, and of sponge-spicules, some of which may have been originally silicious.

3. Some of the moldic porosity was subsequently filled with clear spar cement, which grew inward from fringing bladed spar into a drusy mosaic cement texture. Other open pores such as intragranular spaces (foraminiferal chambers, pores in fragments of algae) filled with fine clear equant spar cement. The mudstone matrix is rather porous, and only some of the larger open pores were occluded with cement. Finally, some of the samples display fractures that were subsequently filled with granular mud and clear equant spar cement.

\section{Interpretations}

The predominance of mud-supported textures indicates a low-energy environment of deposition, such as a platform-lagoon or bay. The assemblage of biota is typical of that of Cretaceous restricted shallow-water marine environment (Enos, 1983). Somewhat bioturbated mudstones and wackestones with a low species diversity indicate a subtidal setting in a lagoon protected from waves and currents. Some evidence of episodic changes in depositional environment occurs in these rocks, but the textural effects of these changes have become obscured by bioturbation: laminae of organic-rich, granular mudstone have been mixed into the more common lime-mud, whereas apparent clustering of particles into patches dominated by single fossil types may likewise indicate episodes of rather restricted conditions, during which species diversity was very low. The environment seems to have varied between rather restricted and more openmarine conditions, the latter indicated by increased bioturbation, occurrence of normal-marine indicator organisms (green algae, sponges [Flügel, 1982]), and debris transported from the shelf margin, including abraded mollusk-shell particles and fragments of coral. Water depth was probably no more then a few meters: deep enough to be subtidal.

When comparing samples from Allison and MIT guyots, those from Allison appear to be consistently richer in green algae, ostracodes, and miliolid foraminifers, whereas those from MIT Guyot contain more biserial foraminifers and sponge spicules. These differences could be attributable to differences in paleolatitude of the two sites (Carranante et al., 1988). MIT Guyot is to the north of Allison, and appears to have a slightly more "temperate" fossil assemblage. The differences could also be due to slight difference in depth of deposition, where the assemblage from Allison Guyot represents the shallower environment.

\section{Facies 3 (Packstone and Grainstone of Peloids, Ooids, and Coated Grains)}

This facies is characterized by the predominance of peloids and coated grains in grainstone or packstone. In addition, a variety of bioclasts occurs, including mollusk and echinoid debris, red and green algae, and benthic foraminifers. Grains of reworked, previously lithified limestone are common also.

\section{Matrix}

Most samples from this facies contain a muddy, micritic matrix that is commonly partially to completely phosphatized (Heezen et al., 1973). This matrix is heterogeneous: patches of dense, dark, relatively mold-free, matrix occur in more common light, clotted matrix with interstitial microspar cement (Fig. A8). The denser matrix tends to contain smaller particles. The sample from Allison Guyot (RNDB D71-14; Fig. A9) has interstitial mud concentrated in the finer-grained horizons.

\section{Particles}

The abundance and types of bioclasts among the coated grains and peloids appear to cover a range from near-reef (many mollusk shells, fragments of red algae, and coral) to distal-lagoon (rare bioclasts of foraminifers and fragments of green algae). The most common particle types in this facies are coated grains and micritic peloids and pellets. Coated grains include ooids, superficial ooids, and aggregate grains. The ooids are partially micritized which has obscured their original concentric structure. Superficial ooids are fine-sand-sized clasts that consist of one or more concentric micritic laminations around mollusk fragments or foraminiferal tests. The cores of most superficial ooids have been dissolved, leaving molds, or recrystallized to fine-crystalline equant spar (Fig. A8). In some grains, concentric layers of micrite coat more than one particle, forming aggregate grains.

Peloids and pellets are very abundant in this facies. Peloids are micritic, rounded grains that can have a variety of origins. They range in size from 0.1 $\mathrm{mm}$ to $2.0 \mathrm{~mm}$. Extensive micritization of algal fragments, foraminifers, and ooids suggests that many peloids may have originated in this way. Others may be small redeposited clasts of mudstone (Fig. A8). Pellets are round and oval micritic particles that have a narrow grain-size range of 0.01 to $0.1 \mathrm{~mm}$. They consist of dark homogeneous micrite and lack any suggestions of preexisting microstructures. Their consistent shape and size suggest they are fecal pellets, produced by small detritus-feeders, such as many types of crustaceans, softbodied invertebrates, and fish (Flügel, 1982).

Bioclasts include fragments of bivalves, gastropods, red and green algae, echinoderm fragments, foraminifers, and coral. The bioclasts are angular and subangular, except where rounded by thick coats of micrite. They range in size from $0.01 \mathrm{~mm}$ to $0.5 \mathrm{~mm}$. Most bioclasts, especially the bivalve fragments, are very poorly preserved. Most are extensively micritized and coated (Fig. A10). Much of the original bioclast material is dissolved, leaving molds. Some mollusk fragments retain part of their original wall-structure.

Mollusks include fragments of Inoceramus, rudists (probably radiolitids) and gastropods. Fragments of algae are common, including green and red algae. Fragments of solenoporan red algae were observed at Jacqueline Guyot (Sample A5-D9-7). Rare fragments of echinoderms occur in all samples and are generally coated with micrite and extensively bored and micritized.

Benthic foraminifers, mostly unidentifiable agglutinated uniserial, biserial, and planispiral forms, occur in most samples. In the partially phosphatized samples with heterogeneous matrices, the foraminifers occur preferentially in the denser, finer-grained parts of the matrix. Chambers are filled with fine microspar cement. A specimen of Favusella washitensis, a planktonic foraminifer that ranges in age from lower Albian to lower Cenomanian (Sartorio and Venturini, 1988) was found on Cape Johnson Guyot (Sample A5-D5-1). Other bioclasts include rare fragments of bryozoans and coral.

Samples from Charlie Johnson and Cape Johnson guyots contain abundant fragments of prelithified limestone. These rock fragments consist of mudstone and pelletal packstone and grainstone. The mudstone fragments can be distinguished from peloids by their more angular appearance and by the abrupt termination of small veinlets and grains at the boundary of the fragments. The pelletal packstone and grainstone fragments are similar to the rest of the material in which they were reworked. They distinguish themselves by being far more diagenetically altered than the surrounding material. Most of the clasts have micritized edges. Some have spar-filled veins that cut through the entire grain and terminate sharply at the grain boundary. The rock fragments range in size from $0.5 \mathrm{~mm}$ to several $\mathrm{mm}$.

\section{Texture}

All samples in this facies have a grain-supported texture, with varying amounts of micrite between the grains. Samples from Charlie Johnson and Cape Johnson guyots are the muddiest. Most of the matrix in those samples 


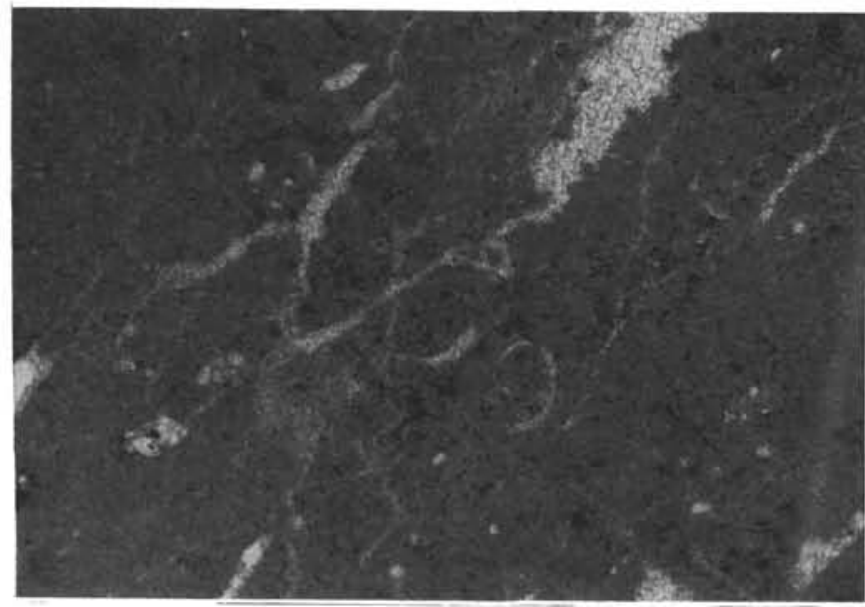

$0.5 \mathrm{~mm}$

Figure A7. Photomicrograph of sparse fossiliferous mudstone (Facies 2). Small, irregular fractures in the mudstone have been filled with clear, equant spar cement (calcite). The small fossil in the center is a gastropod fragment. The straight, light-colored line near the right edge of the photograph is a scratch on the thin-section. Sample RNDB-D56-29-R1.

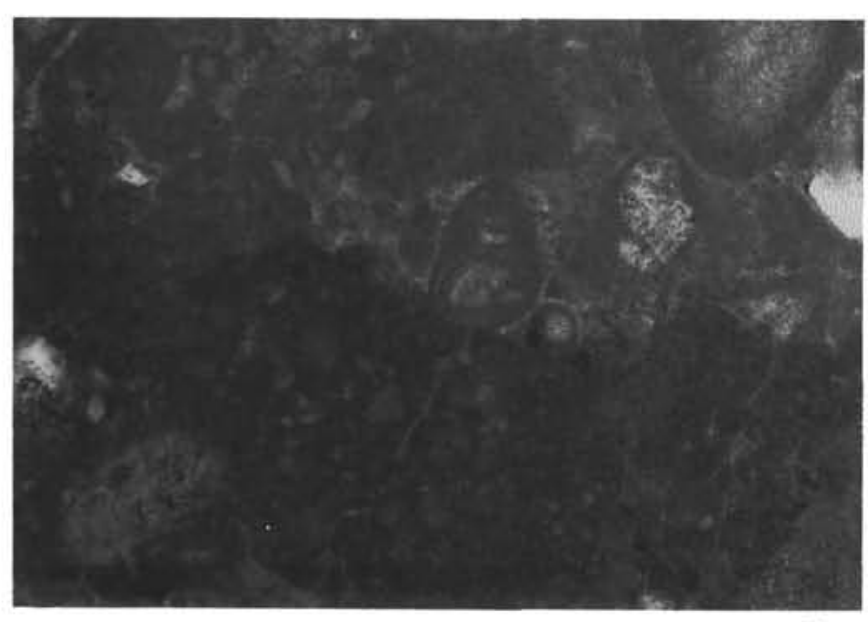

$0.5 \mathrm{~mm}$

Figure A8. Photomicrograph of peloidal packstone (Facies 3). The grains consist of micritic pellets, peloids and partially micritized and coated fossil fragments. The bottom half of the photograph is dominated by dense, dark matrix, whereas the upper half consists of a lighter, clotted matrix with a broader range of particle-size, interstitial microspar cement. Sample A5-D5-1.

appears to have been affected by phosphatization. Little evidence of compaction can be seen, except in some of the rock fragments: grains are touching only tangentially and at extremities. No evidence of sorting or grading occurs, except on Allison Guyot (Sample RNDB D71-14; Fig. A9). This sample consists of 0.2- to $0.5-\mathrm{mm}$-thick graded laminae of pellets and coated grains. Although the orientation of the sample is not known, the gradual transition from coarse to fine, and the sharp boundary between fine and coarse intervals suggest these are fining-upward laminae. The textural inhomogeneity of the muddy samples may have been caused by bioturbation.

Porosity in most samples is high, mostly in the form of molds of bioclasts. Little primary porosity remains: the lightly compacted, rather granular micrite has been completely cemented with microspar. On Jacqueline Guyot (Sample A5-D9-7), grains are cemented by a very fine microspar cement, which may be neomorphic after micrite. Because many grains are surrounded by fine radial-fibrous cement, this micrite would have been a later mud that infiltrated the already partially cemented sediment.

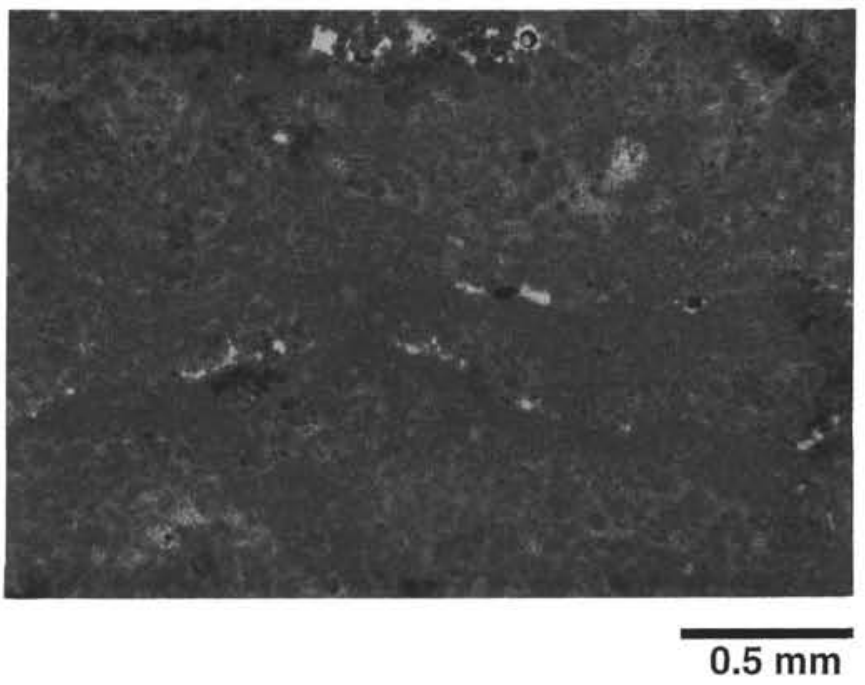

Figure A9. Photomicrograph of peloidal packstone (Facies 3). This sample exhibits fine-scale fining-upward laminae of pellets, coated grains and ooids. Transitions from fine to coarse are sharp, whereas transitions from coarse to fine are gradual. Sample RNDB-D71-14.

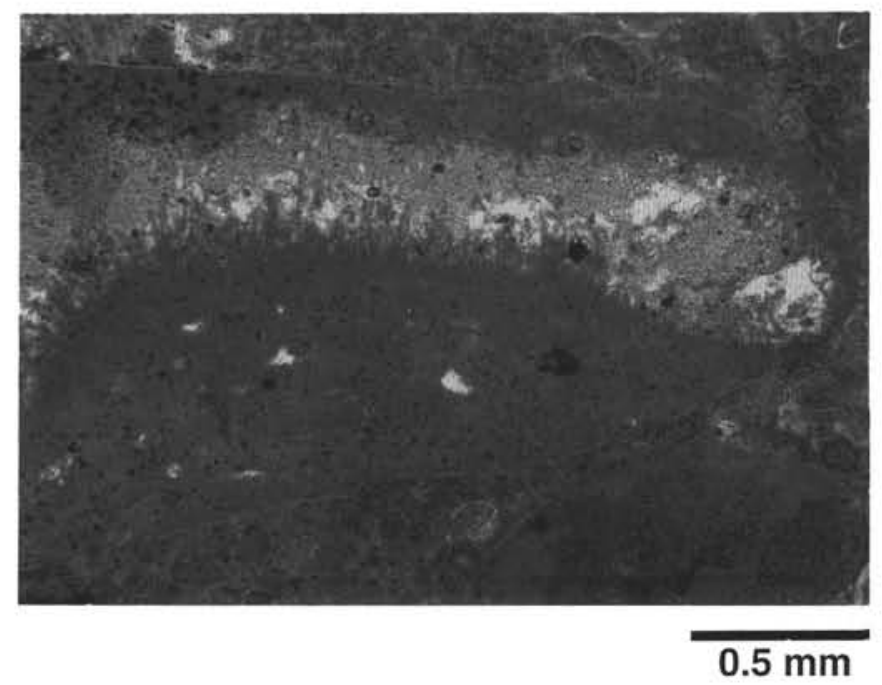

Figure A10. Photomicrograph of peloidal packstone (Facies 3). The large mollusk fragment has been extensively micritized, as indicated by the micritic tendrils that intrude into the particle. Subsequent coating of the fragment with lime mud has trapped small particles and formed a thick layer of micrite around the grain. Sample RNDB-D51-33.

\section{Diagenesis}

The postdepositional history of these samples varied, but began with lithification of micrite matrix and the formation of microspar cement in the lessdense micrite as well as in intraparticular pores such as the chambers of foraminifers and the space inside the structures of algal fragments. This was followed by dissolution of bioclasts, especially of mollúsk fragments, and the partial occlusion of some molds by bladed and clear coarse spar cement. Later diagenetic events include the partial phosphatization of some of the matrix, which does not appear to have affected particles; replacement of limestone by dendritic manganese oxide; and the partial filling of open pores and molds with a cryptocrystalline brown material, probably phosphorite and manganese oxide.

Stylolites were observed in rock fragments at Charlie Johnson Guyot (Sample RNDB-D51-18; Fig. A11). The stylolites form low-amplitude, angular peaks in muddy parts of the fragments, and appear to terminate small veinlets, indicating their formation after formation of veins. Cementation of 


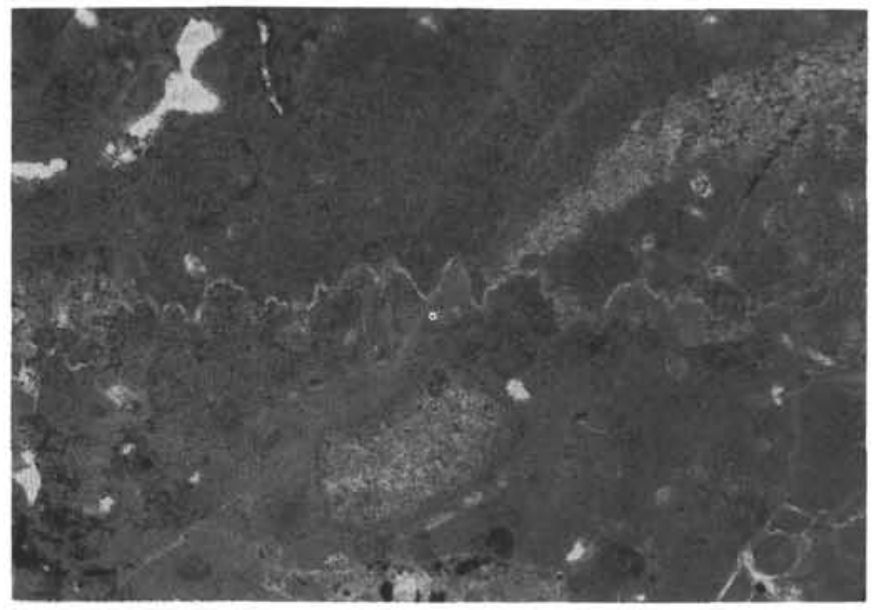

$0.5 \mathrm{~mm}$

Figure A11. Photomicrograph of peloidal packstone (Facies 3). Part of a wackestone rock fragment has a distinct stylolitic structure (bright jagged line) against which small, spar-filled fissures terminate. The edges of the grain are beyond the boundary of the figure. Sample RNDB-D51-18.

pore space, including molds, in the rock fragments is generally complete, although some molds of mollusk shells are not completely occluded, and are lined with coarse, bladed, spar cement.

\section{Interpretations}

The coated grains indicate the original environment of deposition was in moderately agitated shallow water. Extensive micritization and abrasion of most grains indicate they were moved around in well-lighted water prior to final deposition. Grains of reworked, previously lithified limestone may indicate the presence nearby of exposed parts of the platform where this sediment was exposed by erosion. The presence of ooids, superficial ooids, and aggregate grains likewise suggests a periodically well-agitated environment, such as a marginal bank-top or shelf. Bioclasts include particles derived from near-reef environments, such as radiolitid rudists and other thick-shelled bivalves, and red algae. Others, such as agglutinated benthic foraminifers and green algae are more commonly associated with a lagoonal environment.

Samples of this facies from the different seamounts appear to represent slightly different parts of the bank-top environment: samples from Charlie Johnson Guyot contain the most reef-derived material (mollusk debris, echinoids, and even coral), whereas those from Allison Guyot contain the least reef material and the most elements associated with a lagoonal environment (micritized green algae and foraminifers). In between these two extremes are the sample from Cape Johnson Guyot (which has fairly abundant mollusk fragments, but also foraminifers and green algae) and the sample from Jacqueline Guyot (in which foraminifers are more abundant then mollusk fragments). The Facies 3 environment was less sheltered than that of the mudstones of Facies 2, but was inside the platform margin, as indicated by the mixed occurrence of lagoonal and platform-margin derived bioclasts. This environment corresponds most closely to Facies Belt 7 of Wilson (1975): an open platform lagoon, interior of the margin, but well agitated and with open circulation to the ocean.

The occurrence of diagenetically mature limestone rock fragments indicates the presence of elevated (exposed) terrain on Charlie Johnson and Cape Johnson guyots at the time of deposition of these sediments. The presence of stylolites in these fragments indicates that they were eroded from previously buried limestone. The depth of burial required for microstylolites to form may be only a few tens of meters (Schlanger, 1964), but usually requires a few hundred meters of overburden to develop. The microstylolites in these samples appear to be completely nontexture controlled, indicating that the sediments were well lithified and diagenetically mature when the stylolites formed. The presence of exposed, previously buried limestone may support the hypothesis that the guyots were uplifted and their limestone summits exposed as much as $180 \mathrm{~m}$ some time in late Albian-early Cenomanian time. Such uplift and exposure is suggested on the basis of geophysical and morphological evidence (van Waasbergen and Winterer, 1993; Winterer et al., 1993).

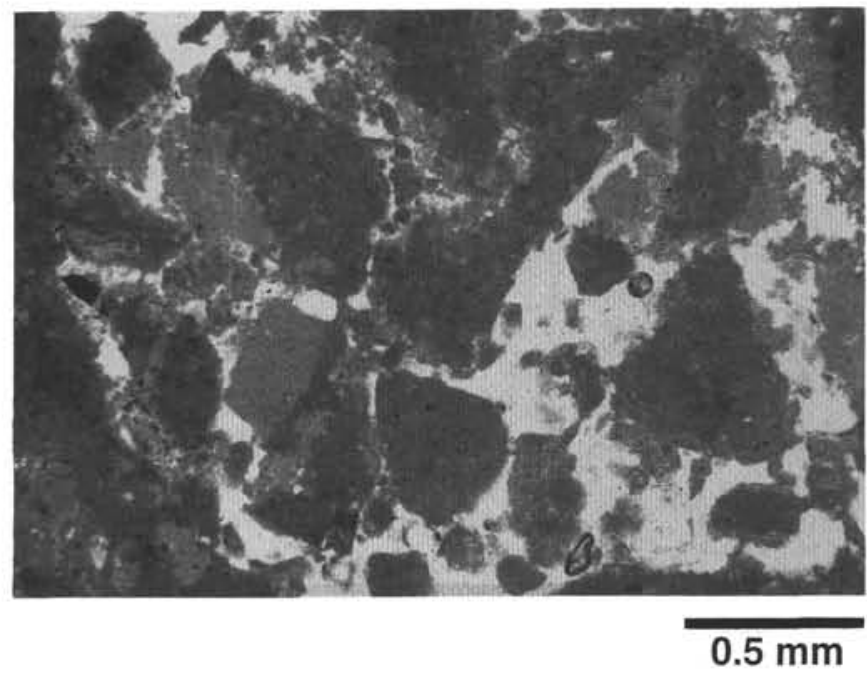

Figure A12. Photomicrograph of sponge-algal bafflestone (Facies 4). Note sheltered part of matrix between large sponge-algal structures. Micritic intraclasts are loosely bound with micrite. Bright areas are void space. Sample RNDB-D71-10.

\section{Minor Facies}

The following rock types were identified only in minor amounts and in single dredges. Most of them were found on Allison Guyot, which, with six successful dredge-attempts (Fig. 11), is one of the most widely-sampled of the Cretaceous Pacific guyots.

\section{Facies 4 (Bafflestone of Large Sponge and Algae Structures with a Peloidal and Bioclastic Muddy Matrix)}

This facies is characterized by packstone and wackestone of fine sand- to silt-sized micritic particles and bioclasts of foraminifers, coral, mollusks, and echinoderms, as well as wackestone rock fragments in a porous matrix in which large structures of encrusting algae and massive calcareous sponges occur.

\section{Matrix}

The matrix consists of chalky, loosely packed micrite light gray in color, which appears to form small, rounded clots about $0.02 \mathrm{~mm}$ in size. Some of the matrix was recrystallized to very fine spar. Patches of micrite are fairly homogeneous, but areas between the large algal and sponge structures differ from one another in density and particle abundance, which suggests the matrix may be a secondary infilling of the space between the sponge and algal structures.

In sheltered parts of the matrix, and in partially filled molds of bioclasts, the matrix consists of a very loose, open structure of fine-sand-sized subangular micritic clasts that are loosely held by micritic cement that often forms bridging structures connecting individual grains across a void space (Fig. A12). This fabric closely resembles meniscus cement fabrics commonly associated with precipitation in the vadose zone (Flügel, 1982).

\section{Particles}

Particles include common bioclasts of foraminifers, mollusks, red algae and echinoids, and abundant micritic particles, including peloids, intraclasts and wackestone rock fragments. Among the foraminifers, the most common forms are micritic agglutinated biserial forms (textularids), miliolids, and fragments of Orbitolina. In addition, many samples contain specimens of thick-shelled hyaline forms (possibly rotalids) and rare planktonic foraminifers including Planomalina buxtorfi (I. Premoli Silva, pers. comm., 1990), which has a narrow biostratigraphic range within the late Albian (Sarterio and Venturini, 1988). Chambers are commonly filled with fine equant spar cement, or can be unfilled.

Mollusk fragments include fragments of Inoceramus, gastropods, and radiolitid rudists that can be up to several $\mathrm{mm}$ in size. Mollusk fragments commonly have micritized outer shell walls, whereas the rest of the shell 
material may be entirely dissolved, recrystallized, or partially preserved. Where dissolved shell material has left large molds, the pore space is commonly filled by loosely bound micritic particles and small bioclasts in what appears to be a vadose meniscus cement fabric.

Fragments of red algae are rare to common as angular, elongate bioclasts with a fine-mesh microstructure. The algal fragments are partially micritized, but some of their fine microstructure remains visible.

Rare echinoid fragments form poorly preserved, partially micritized and abraded fragments, silt- to fine-sand-sized, that can be identified in thin sections by their single-crystal extinction. The cores of many of these particles were recrystallized to an equant polycrystalline texture.

Micritic particles in the wackestone matrix include fine-sand-to sand-sized peloids, intraclasts, and wackestone rock fragments (Fig. A12). The rounded peloids are difficult to distinguish within the identical surrounding mud, except in the porous parts of the matrix. Intraclasts are angular and subangular clasts of mudstone, with clearly distinguishable grain boundaries, but otherwise identical to the common wackestone matrix. Rock fragments include angular clasts in which small spar-filled molds can be observed to terminate against grain boundaries. Whereas the intraclasts may be derived by early in-situ redeposition of slightly lithified mud, the rock fragments appear to be diagenetically more advanced, because spar-filled molds are virtually nonexistent in these sediments. Other micritic particles occur within the irregular spongestructures (Fig. A13). These silt-sized, round, dark-micritic particles may be small fecal pellets.

\section{Massive Sponge, Coral, and Algal Structures}

Bulbous and irregular-shaped, commonly hollowed structures up to $2 \mathrm{~cm}$ in size occur throughout these rocks. In hand samples, these are often observed as light gray, porous limestone patches and irregular cavities lined with muddy casts of corallites, indicating some of them are molds of coral knobs. Some of them appear to have small "stems" that give them the appearance of fragments of cauliflower. In thin section, the sponge structures (Fig. A13) consist of irregular walls that enclose chambers and channels 0.1 to $1 \mathrm{~mm}$ in size and are coated with fine fringing and equant spar cement. The space enclosed by these walls is commonly filled with wackestone matrix or pelletal grainstone, whereas the walls themselves are filled with dense micrite (Fig. A13) or remain void-space partially occluded with equant spar. The outer edges of the structures are commonly coated by encrusting coralline algae. Individual algae can be traced over several millimeters in a single thin section. The hollow aspect of these structures can most likely be attributed to dissolution of the framework-material, which has left large cavities, which in some places are lined with imprints of corallites.

\section{Texture}

The bulk of these sediments consist of porous brown-gray wackestone with sand-sized micritic particles and abraded bioclasts. Individual patches of wackestone are fairly homogeneous and show no evidence of sorting, grading or lamination. Within these patches are uncemented cavities, mostly molds of larger bioclasts, in which a very loose meshwork of micritic grains held together by small amounts of micritic cement occurs. The patches of wackestone occur between large, irregular shaped sponge, coral and algal framework bodies, which acted as stabilizing structures. No evidence of compaction was recognized.

Porosity throughout is very high. Primary porosity includes interparticular pore space in the loose wackestone, which is only partially occluded with crystalline cement. Primary growth-framework pore space in coral/sponge/ algal structures is largely filled with mud. Secondary porosity includes large and small molds of bioclasts, generally without any crystalline cement. Some molds may have been enhanced by solution. The largest cavities are those where coral and sponge structures have been dissolved away. Within the preserved sponge-structures, original wall-material has commonly been removed, leaving open, spar-lined channel-like pores among the infilling pelsparite and wackestone matrix.

\section{Diagenesis}

Syndepositional alteration includes boring and micritization of bioclasts. Most fine-sand and smaller sized particles have been thoroughly micritized. Early postdepositional diagenesis includes the infilling of coralline and sponge structures with mud and pellets. Following lithification of the sediment, including the precipitation of fine-crystalline equant spar in the loose pelletal silt parts of the matrix, unstable minerals dissolved, leaving largely unfilled

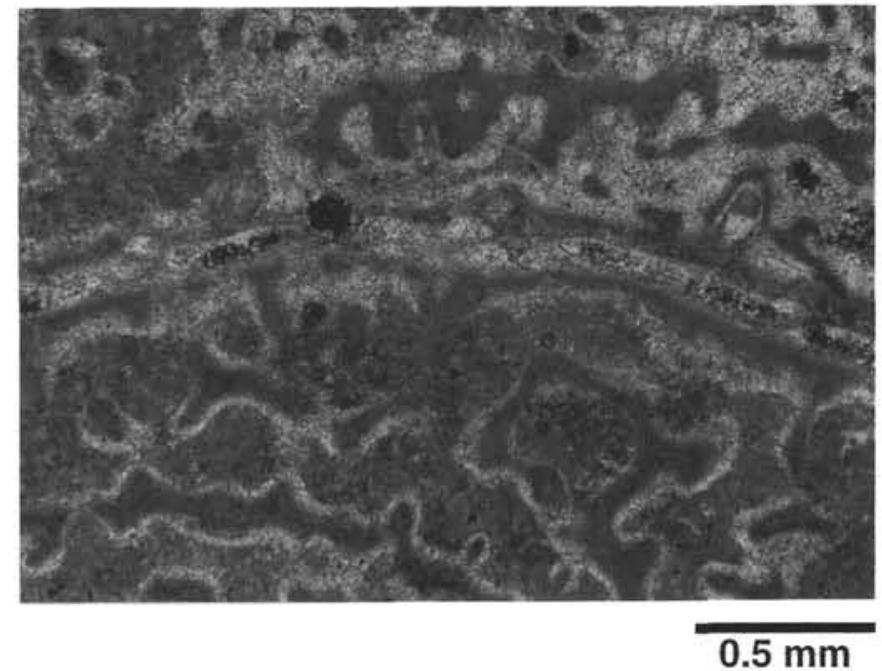

Figure A13. Photomicrograph of sponge-algal bafflestone (Facies 4). The sponge structure has cavities that are partially filled with mud. The walls of the original sponge body are micritized and lined with fine, fibrous spar cement (calcite). Sample RNDB-D71-13A.

open molds. This may have occurred at the same time as recrystallization of the echinoderm fragments.

Very fine-crystalline, marine, fringing-spar cement lines many of the open molds. These became subsequently partially filled with micritic particles cemented by what appears to be meniscus micrite cement. This suggests that these rocks have undergone a brief episode of vadose diagenesis, likely very early in the diagenetic history, after initial lithification, and perhaps contemporaneous with the dissolution of unstable mineral grains.

\section{Interpretations}

The centimeter-size coral, sponge, and algal structures may be part of a small bioherm. Trapped between these structures are large radiolitid rudists, in peloidal mud containing abundant lagoonal organisms such as micritic benthic foraminifers and algae. Bioclasts associated with platform margin and fore-slope deposits (mollusks and echinoids) occur rarely and are generally abraded and micritized, indicating the source for such particles may be relatively far away. These elements suggest deposition occurred on small mounds inside the platform margin, which may have become emergent as indicated by the apparently vadose secondary diagenetic textures. Other indicators of emergent terrain include locally derived lithoclasts (pieces of barely firm mud at time of deposition) and diagenetically advanced wackestone rock fragments. The relatively common occurrence of planktonic foraminifers in the matrix indicates an open circulation with the ocean.

\section{Facies 5 (Silicified Oolites)}

Samples that belong to this facies were dredged from the edge of a small plateau about $5 \mathrm{~km}$ in diameter that stands about $100 \mathrm{~m}$ above the main summit plateau on Vibelius Guyot. They consist of poorly preserved, wholly siliceous oolite grainstone. Sample RNDB D59-1 is a solid, nonporous siliceous rock, and in sample RNDB D59-2 all the ooids have been removed, leaving oomoldic porosity in a fine-grained siliceous matrix.

\section{Grains}

Ooids and oomolds up to $2 \mathrm{~mm}$ in diameter show (in Sample RNDB D59-1) relict cortical structures, indicating these were tangential-laminated rather than radial ooids (Fig. A14). No nuclei remain in either sample. The concentric structures occur as brown, discontinuous laminae of micrite. Between the relict carbonate laminae, the ooids consist of chert or microcrystalline quartz that forms small subrounded optically continuous patches and clusters up to 0.1 $\mathrm{mm}$ in diameter. The chert patches are observed to enclose the carbonate crystals as poikilitic cement. In some ooids, clotted micrite occurs between quartz patches (Fig. A14). Near the outer boundary of the ooids, there typically 


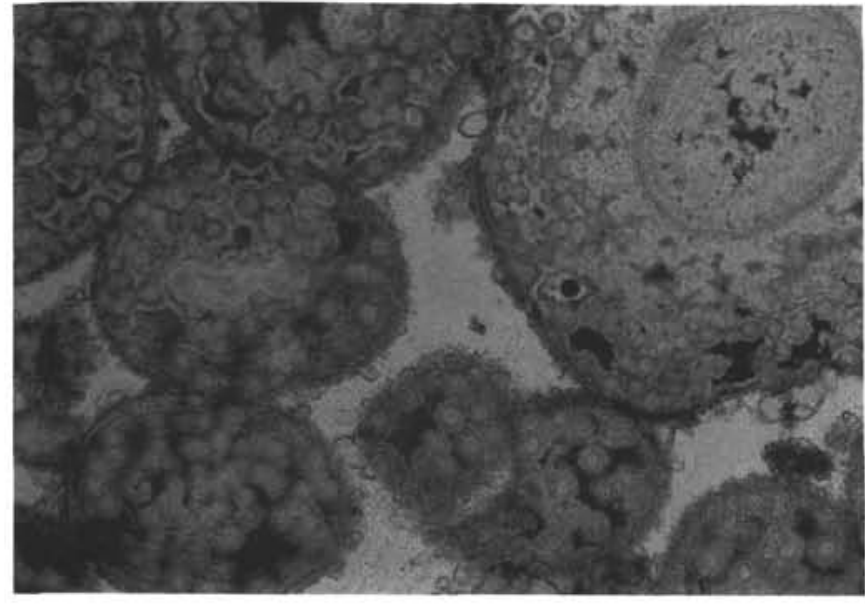

$0.5 \mathrm{~mm}$

Figure A14. Photomicrograph of silicified ooid grainstone (Facies 5). Original concentric layering in the ooids is preserved as traces of microcrystalline calcite. The rest is completely replaced with fine-grained silica. Euhedral quartz forms small equant crystals within the replaced ooids. Sample RNDB-D59-1.

occurs a $10-\mu \mathrm{m}$-wide lamina of small equant quartz crystals that lies just inside a $20-\mu \mathrm{m}$-thick lamina of fine micritic calcite that defines the outer edge of the original ooid.

\section{Matrix}

The ooids are cemented by isopachous calcite cement, which grades into chert only a few tens of microns into the material between the grains. The chert cement replaces the original two-generation calcite cement so as to preserve the original cement texture: isopachous radial fibrous or equant spar increases in crystal size into the pores to form a coarse, pore-filling blocky cement. Some calcite crystals have been preserved as inclusions in the chert, especially at the transition between the isopachous fringe and the void-filling blocky cements (Fig. A14)

\section{Texture}

The original texture of these samples was grain-supported. No evidence of interstitial mud occurs, but alteration to silica has removed most of the calcite. The cement texture of the silica pseudomorphs after originally sparry calcite suggests that these were well-washed grainstones, without interstitial mud. Grains appear to have touched mostly tangentially, but some grains appear to have fused by pressure solution (Fig. A14), indicating that some compaction occurred.

\section{Interpretations}

These samples appear to be originally calcite-cemented oolitic grainstones that have become nearly completely replaced by silica. The ooids were tangential rather than radial, based on the occurrence of concentric rings of relict micrite in the now-siliceous grains. The original environment of deposition, as indicated by the well-sorted, apparently well-washed textures, was probably one of strong agitation, such as a beach or ooid sand shoal. Original cement textures are reminiscent of beach-rock cementation. Overall, the original sediment-textures and composition are consistent with deposition in Standard Facies Zone 6 of Wilson (1975) (winnowed platform-edge sands). These were the only siliceous sediments recovered in any of the dredges on the guyots. The causes of silicification and the source of silica are not known.

\section{Facies 6 (Mixed Carbonate and Siliciclastic Sand)}

This material was dredged from the northwest side of Allison Guyot. Only a handful of material was recovered in the dredge, only one sample of which was thin sectioned. The rest of the material appeared, in hand-specimen observations, to be of the same facies. The facies is characterized by a mixture

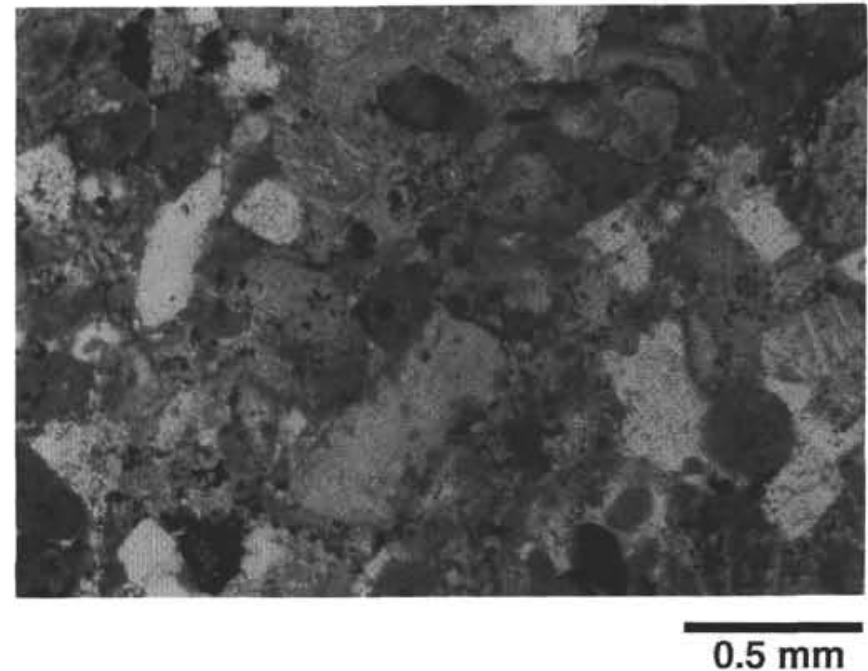

Figure A15. Photomicrograph of mixed carbonate and siliciclastic sandstone (Facies 6). Carbonate grains include micritic peloids, bioclasts (mollusk and echinoderm fragments). Siliciclastic grains include untwinned feldspar, altered mafic rock fragments, biotite flakes, and abundant opaque minerals. Sample RNDB-D69-1.

of shallow-water-derived, sand-sized grains and siliciclastic sand, tightly compacted and slightly cemented with micritic calcite and clayey alteration products (Fig. A15).

\section{Grains}

Shallow-water-derived carbonate grains $(70 \%)$ include micritic intraclasts and peloids, carbonate rock fragments, and bioclasts including red algae, micritized bivalve fragments and fragments of echinoids (Fig. A15). All the grains appear to have been thoroughly rounded and micritized, indicating they may have been transported over some distance. The rock fragments include fragments of prelithified wackestone as well as fragments of crystalline limestone).

The siliciclastic grains (30\%) include untwinned feldspar crystals (abundant), rare twinned feldspar crystals, highly altered mafic rock fragments (common), biotite flakes, altered glass shards, and opaque minerals, some of which may be authigenic in origin.

\section{Texture}

The sediment is well-compacted, with flexible grains such as biotite flakes deformed around more competent grains. Some micritic carbonate fragments appear to have been deformed, indicating they may still have been partly lithified at time of deposition. Intergranular porosity is very low due to the tightly compacted, interlocking nature of the grains, and what little porosity there was has been filled with micritic carbonate and a reddish-brown cryptocrystalline material, which is probably an alteration product of some of the siliciclastic components (Fig. A15).

The material is well-sorted, medium- to coarse-grained sand, with no indication of lamination, bedding or grading visible in the thin section. Most of the siliciclastic grains are angular and subangular, whereas the carbonate grains are rounded and subrounded. Small, generally irregular-shaped equant opaque grains are common throughout. These are probably authigenic in origin, since they can occur between, but also inside, other grains (Fig. A15). Some of these, though opaque in thin section, have a reddish tinge, which suggests they may be hematite.

\section{Diagenesis}

Little postdepositional alteration of grains is evident. Mollusk fragments appear to have retained relict microstructures, though they are most likely recrystallized. A few echinoid fragments have thin rinds of syntaxial cement, which appears to be secondary to deposition: the rinds extend up against other grains, and are halted by the presence of interstitial mud. This indicates the 
syntaxial cement postdates the interstitial micrite, and was not deposited with the echinoid fragments. Other diagenetic processes that have affected this material include compaction and grain deformation, alteration of volcanic grains, and the production of reddish, cryptocrystalline interstitial material.

\section{Interpretations}

The grain-size distribution, well-sorted sand, indicates a environment of deposition of consistently high to moderate energy, such as on a beach or on a tidal-current-swept portion of a shallow shelf. Another possibility is that these sediments were deposited as turbidites, but there is not a sufficiently large sample available to recognize that. The volcaniclastic grains are fairly angular, indicating they were rapidly deposited after they were produced.

The carbonate components are mostly micritic grains and rock fragments of wackestone, with only minor contributions of platform bioclasts such as bivalves and algae. This indicates the source of the carbonate grains lies mostly in the backreef and lagoonal parts of the platform. Most of the siliciclastic material appears to be derived from a volcanic source. The rock fragments appear to be fine-grained basalt fragments. The presence of biotite flakes and common untwinned feldspars is somewhat unusual on a basaltic seamount, and may indicate the source rock was a fairly evolved form of basalt, perhaps indicative of late-stage volcanism of the volcanic edifice during the evolution of the carbonate platform.

\section{Facies 7 (Packstone of Peloids with Abundant Planktonic Foraminifers)}

This facies is characterized by loosely packed micritic clasts in a matrix of slightly recrystallized homogeneous micrite. Clasts include peloids, mollusk fragments, echinoid fragments, micritic benthic foraminifers, and planktonic foraminifers.

\section{Matrix}

The interstitial material consists of a fairly homogeneous lime mud, which is very loosely packed and commonly recrystallized to microspar. Small irregular opaque spots throughout the matrix may be authigenic patches of manganese oxide. The matrix fills the space between the grains incompletely, leaving much intergranular porosity. Although the sediment has a grain-supported texture, the matrix appears to be primary: there is no evidence of any intergranular crystalline cements predating the interstitial mud, and none of the abundant molds appear to have been filled with mud.

\section{Particles}

Most (about $90 \%$ ) of the particles are rounded micritic grains (peloids) with a variety of origins. Some appeared to have formed from micritization of bioclasts including foraminifers, mollusk fragments and fragments of algae, whereas others originated as fecal pellets, and as rounded mud clasts (intraclasts). Grains are fine- to medium-sand-sized, and generally well rounded. Fecal pellets are round and oval in shape, whereas peloids from other origins can have very irregular shapes (Fig. A16).

The next most common type of particle (about 5\%) is the echinoid fragment. These can be very large, up to several millimeters in diameter. They are generally well-rounded, with thin micritic rinds and retain their characteristic optical property of unit-extinction under crossed nichols. Fragments are occasionally overgrown with syntaxial, optically continuous clear calcite cement that appears to have been limited by the presence of interstitial mud.

Mollusk fragments (about $3 \%$ ) range in size from fine sand to up to several millimeters in diameter. Molds of mollusks (mostly bivalves) are common. The grains are extensively bored and coated with micrite up to $0.2 \mathrm{~mm}$ thick. In some grains, original growth structure of the mollusk shells has been preserved, although most have been recrystallized or dissolved to molds. Recognizable mollusk fragments include those of radiolitid rudists (Fig. A17).

Benthic foraminifers occur throughout (about 1\%), including biserial and uniserial forms, as well as fragments of larger orbitolinid-like forms. Foraminiferal tests generally consist of slightly darker, finer-grained micrite than the surrounding matrix. Chambers are filled with fine-crystalline equant spar cement. Fragments of a thick-shelled, bright (hyaline) form are common, possibly a rotalid foraminifer. No miliolids were observed.

Planktonic foraminifers are ubiquitous in these sediments. They are generally well-preserved or slightly recrystallized. They occur in two modes: as individual grains in the matrix, and loose in cracks and molds. The ones occurring as original sediment grains are commonly slightly recrystallized, and include Favusella washitensis (Fig. A17), Planomalina buxtorfi (Fig. A18), P.

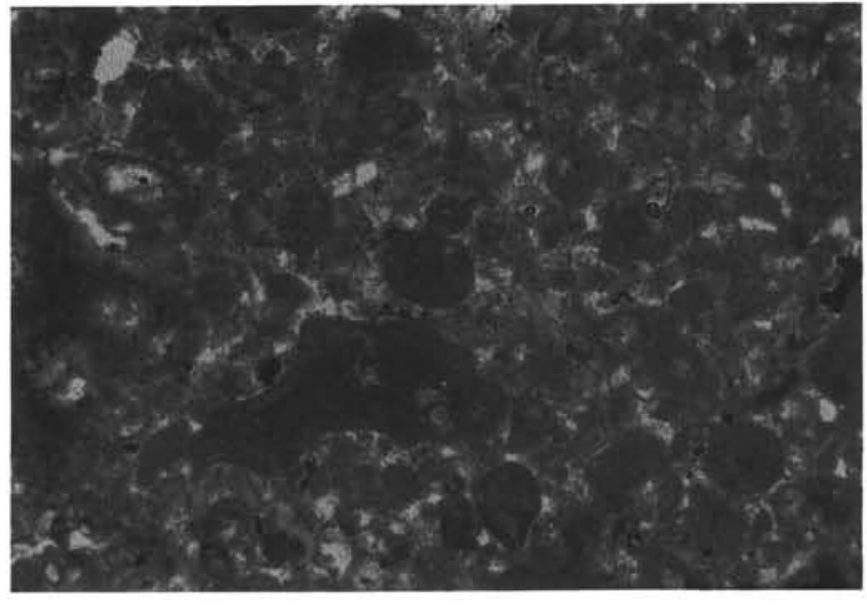

$0.5 \mathrm{~mm}$

Figure A16. Photomicrograph of peloid packstone (Facies 7). Most of the peloids are round to oval in shape and may have originated as fecal pellets. Others are more irregular, and probably represent micritized bioclasts. Sample RNDB-D73-3.

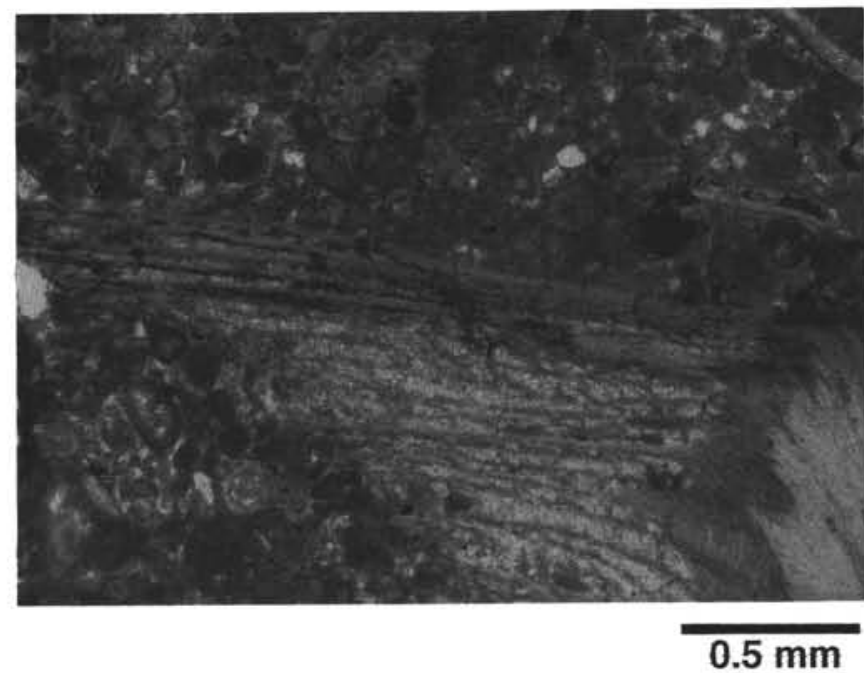

Figure A17. Photomicrograph of peloid packstone (Facies 7). Note large fragment of a radiolitid rudist (center) surrounded by rounded micritic grains (peloids). A specimen of Favusella washitensis is present in the lower left side of the photograph. Sample RNDB-D73-3.

praebuxtorfi, Hedbergella rischi, and members of the Ticinella roberti group (I. Premoli Silva and W. Sliter, pers. comm., 1990). These all form a late Albian assemblage. The planktonic foraminifers that occur in open cracks and molds in the limestone are generally fragmented, though better preserved and span a much wider range of stratigraphic age, from Late Cretaceous to Cenozoic.

Other grains include small $(0.2-0.5 \mathrm{~mm})$ worm tubes, rare fragments that resemble plant seeds, and poorly preserved, nearly completely micritized fragments of green algae. Small $(0.05-0.1 \mathrm{~mm})$ patches of opaque material occur throughout; these are most likely manganese oxide. They occur between grains, but also inside molds, and are therefor likely secondary, authigenic deposits.

\section{Texture}

The sediments are grain-supported, with a mud matrix that fills most, but not all of the intergranular space. Little compaction has occurred. Porosity is high, mostly as molds, but in some parts of the rocks intergranular porosity is important. The grains appear to be well sorted, fine- to medium-sand-sized, 


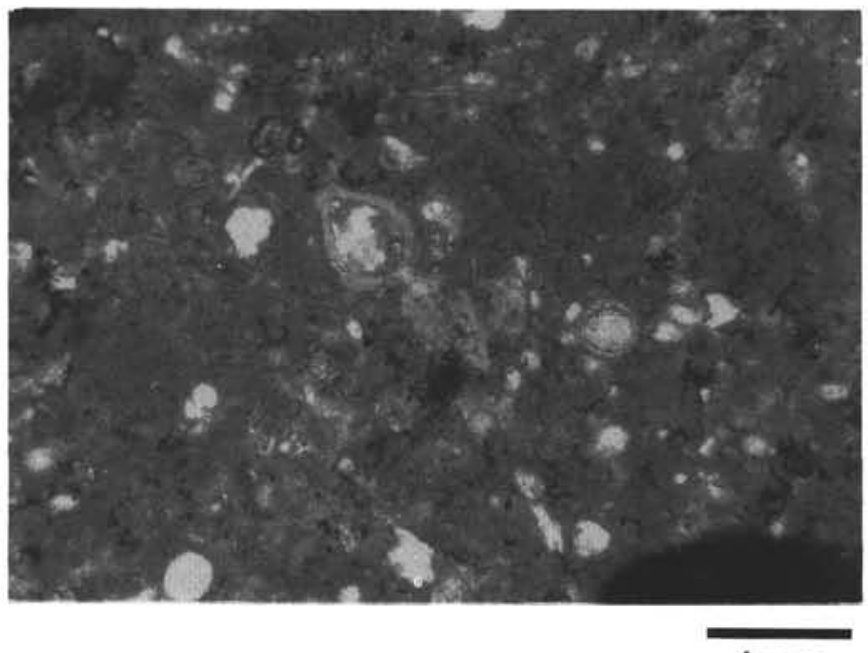

$1 \mathrm{~mm}$

Figure A18. Photomicrograph of peloid packstone (Facies 7). A specimen of Planomalina buxtorfi, a planktonic foraminifer, is surrounded by peloids. Sample RNDB-D73-25.

although bioclasts up to several $\mathrm{mm}$ in size occur. No evidence of bedding or lamination was observed in the thin sections. These rocks commonly contain fractures, some of which are filled with debris of planktonic foraminifers, which also occurs in some molds.

\section{Diagenesis}

These sediments are diagenetically relatively immature. Diagenetic events included partial recrystallization of the mud matrix to microspar, which cements most of the rock; dissolution of some bioclasts, leaving molds; and recrystallization of others. Crystalline cements occur as syntaxial overgrowths on echinoid fragments. In addition, some of the open pores and molds are coated with a fringe of very finely crystalline spar. A few of the molds are fully or partially occluded with clear, equant, sparry calcite, as is most of the intraparticular pore space, including the chambers of foraminifers and the insides of worm-tubes. Finally, manganese oxide deposits formed in parts of the remaining pore space, probably at the same time as the cryptocrystalline reddish-brown material, which is probably phosphorite.

\section{Interpretation}

The abundance of rounded micritic particles in these sediments indicates they originate in well-agitated water, where boring endolithic algae were active, but particle sizes were kept relatively uniform. This suggests an origin in an open lagoon or shallow open shelf. Mixed with these particles are apparently transported bioclasts of mollusks, including radiolitid rudist fragments, and abundant echinoderm fragments. This suggests a slightly deeper source of sedimentation than most of the platform sediments. The echinoids tend to be more abundant in forereef-slope settings (cf. Facies 1), below the wave base. The muddy matrix with abundant planktonic foraminifers likewise suggests a sub-wave-base environment that is open to the pelagic realm, such as might occur on the slope of the platform. None of the platform facies is as rich in planktonic foraminifers. In conclusion, these sediments, especially the peloids and most bioclasts, were probably derived from the shallow platform, but were transported to the slope of the carbonate platform and deposited with pelagic sediments in what most closely corresponds to Standard Facies Belt 3 of Wilson (1975). Depth of sedimentation would be below the normal wave base, but above the storm wave base, in a few meters to a few tens of meters of water

\section{Facies 8 (Packstone and Wackestone of Bioclastic Debris in a Pelletal, Bioturbated Lime-mud Matrix)}

This facies is characterized by the presence of large bioclasts of mollusks and algae in a heterogeneous, well-bioturbated micrite matrix. Grains include gastropods and other mollusks, algae, foraminifers, echinoderm fragments, and micritic particles.

\section{Matrix}

Most of the sediment consists of fine-grained, tan, slightly recrystallized micrite with small bioclasts. Within this wackestone occur irregular-shaped patches of dark, dense, granular micrite much like similar material in the mudstones of Facies 2. A third form of mud occurs in areas with sharper, but highly irregular, almost angular, boundaries with the surrounding tan micrite. This third mud consists of fine sand to silt-sized pellets and micritic granules in fine-crystalline, equant, microspar cement. The irregular boundaries suggest this material may be a secondary sediment that fills in small cracks and vugs in the host wackestone. Small bioclasts commonly occur in both the tan and the granular mud, but are very rare in the pelletal mud (Fig. A19).

\section{Particles}

Particles range from silt-size to several centimeters in size and include large, whole gastropod shells, smaller fragments of bivalves, fragments of red and blue-green algae, benthic foraminifers, and ostracodes. In addition, micritic rock fragments up to $1 \mathrm{~mm}$ in diameter occur.

The gastropod shells are completely dissolved, and the molds filled with cloudy bladed and clean, clear blocky calcite spar cement. The insides of the shells are commonly filled with mud, although some shelter-porosity (now filled with spar cement) commonly occurs in the inner whorls. The shells were slightly micritized before dissolution, although the micritic outer envelope is difficult to distinguish from the surrounding tan matrix. Other mollusk fragments include fragments of bivalves, which are generally completely recrystallized, leaving micritic relics of the original wall structure in the nowcrystalline shell fragments.

Fragments of algae are common, generally 0.5 to $2.5 \mathrm{~mm}$ in size. Algae types include cellular green algae, and radial-bifurcating blue-green algae. Intraparticular pore space in the algal fragments is generally filled with fine-crystalline, equant, spar cement, whereas the algal structures themselves are entirely micritic.

Echinoderm fragments are a minor component in these sediments, but stand out by their characteristic optical properties. Most echinoderm fragments have been rather severely micritized and bored, forming a micritic envelope as thick as $0.2 \mathrm{~mm}$ on most fragments.

Foraminifers include small uniserial and biserial forms, but more commonly miliolids. The micritic tests are difficult to distinguish in the surrounding matrix, but the chambers are generally filled with fine, equant, spar cement.

Ostracodes are locally abundant, especially inside the large gastropod shells. The ostracode tests are small (0.1-0.2 mm long), very thin-walled, and generally disarticulated.

Micritic particles 0.1 to $2.0 \mathrm{~mm}$ in size are common throughout the tan matrix. These appear to be subangular to subrounded fragments of previously lithified mudstone and wackestone. Some have slightly recrystallized interiors. Most have a well-defined, slightly denser or darker micritized outer rind.

\section{Texture}

The nonhomogeneous appearance of the sediment may be in part due to bioturbation. No obvious burrow-structures can be identified. The present porosity is very low. The original porosity appears to have been low as well, not counting the microporosity of the mud. Only sheltered places such as the insides of gastropod-shells and chambers of foraminifers and algae appear to have been free of muddy infilling. Subsequently, porosity was apparently increased by dissolution of bioclasts, some of which was enhanced to form small vugs (Fig. A20). These vugs, and the molds of bioclasts, became later filled with clear and cloudy spar cement, leaving almost no primary or secondary porosity.

Little evidence of compaction can be seen: grains are rarely touching, and touch only at edges. No flattened structures occur, and there is no evidence of pressure-solution. Sorting is very poor: grains of a large range of sizes are mixed together with no apparent grading or bedding.

\section{Diagenesis}

These are diagenetically relatively mature rocks. Most of the unstable minerals appear to have been completely dissolved and the remaining pore space filled with stable calcite cements. Diagenesis included the following: lithification of mud, followed by dissolution and recrystallization of bioclasts, especially mollusks. Some of the matrix was dissolved as well, enlarging molds and producing small vugs. At some point, the pelletal internal sediment entered some of the secondary pore space, creating the third matrix. Precipitation of cement, first of bladed, fringing, cloudy calcite crystals, followed by 


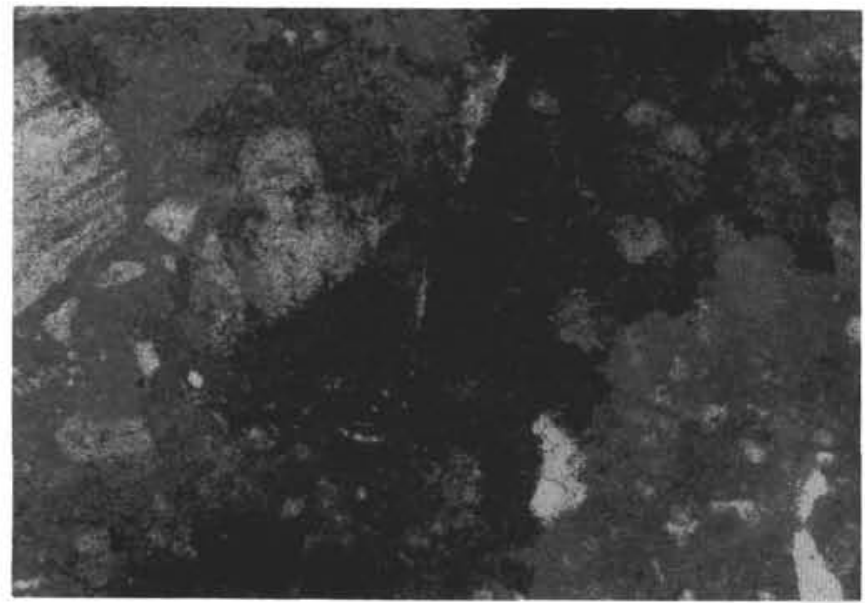

$0.5 \mathrm{~mm}$

Figure A19. Photomicrograph of bioclastic packstone (Facies 8). Note elongate patch of granular micrite (center) between lighter colored tan micrite. Small, angular fragments of bioclasts occur throughout. Sample RNDB-D67-24.

clear, larger equant crystals, occluded most of the remaining pore space. Only the centers of the largest pores remain unfilled, but this may also be a result of latest stage dissolution of the centers of the pores.

\section{Interpretation}

Most of the bioclasts do not show many signs of transport. The only exceptions are the small bivalve and echinoid fragments. This indicates a

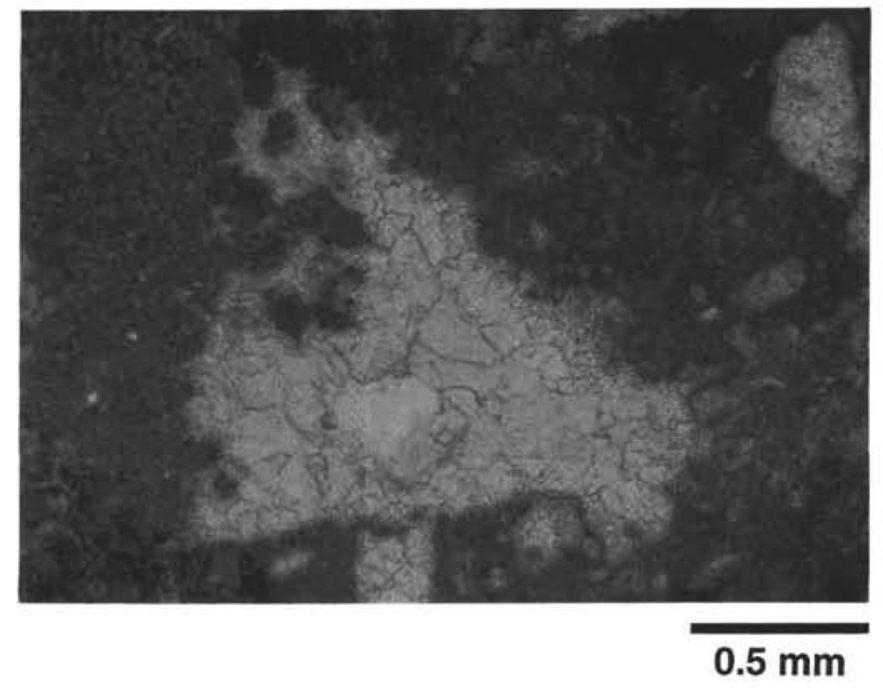

Figure A20. Photomicrograph of bioclastic packstone (Facies 8). Small vug in bioclastic wackestone matrix. The bottom of the vug is lined with finely clotted mud, the remainder filled with clear, equant spar cement. Sample RNDB-D67-24.

largely in-situ assemblage of gastropods, foraminifers, and algae in a muddy environment of low to moderate energy, with occasional influx of pelletal silt, probably subtidal and below the wave base, but well lit so algae could thrive. Particles transported into this environment include the micritized bivalve and echinoid fragments, and the intraclasts and wackestone rock fragments. High species diversity indicates open-marine (not restricted) conditions such as might occur in an algal meadow within the lagoon of the carbonate platform, sheltered behind the platform margin facies. 